\title{
Az önkormányzati honlapok szakszerủ tesztelése és használhatósága közötti kapcsolat
}

\section{Csak akkor terjed jobban az e-közigazgatás, ha jól használhatók az online felületek}

2019 során négy önkormányzat weboldalát vizsgálták a szerzők. Arra voltak kíváncsiak, hogy vajon jobban használhatók-e azok a felületek, amelyeket felhasználói teszteléseknek vetettek alá? Jobbak-e az e-közigazgatási felületek? Az egyes oldalakat többek között a BM ÖFFK II.1 kutatása, valamint a tervezők-fejlesztők információi alapján mutatják be. Az oldalak felületeit Nielsen heurisztikái, valamint Shneiderman aranyszabályai szerint elemezték. Azokban a városokban, ahol fejlettebb az IT-háttér, a tervezés-fejlesztés során kutatásokat is végeznek, így végeredményben jobban használható felületek készülnek. Ugyanakkor jellemző a rosszul megválasztott User eXperience kutatási módszertan és/vagy tesztelői összetétel. Ugyancsak előfordul, hogy felületek nem kellő módon és mértékben akadálymentesek. Idegen nyelvű verzió sporadikusan érhető csak el. Az önkormányzatok online felületei sok esetben elmaradnak attól a szinttől, amivel az állampolgárok minden nap találkoznak az egyéb szolgáltatók weboldalain. Konzekvens és szakszerü felhasználói kutatással és teszteléssel pedig orvosolható (lenne) a probléma.

Kulcsszavak: online kommunikáció, website usability, e-government, önkormányzati és közigazgatási weboldalak

\section{Köszönetnyilvánítás}

A szerzők köszönetet mondnak az érintett városok önkormányzatának, amiért a kutatásukat kitartóan támogatták azzal, hogy válaszoltak a - a sokszor feltételezhetően fárasztó - tervezéssel, fejlesztéssel, kutatással és teszteléssel kapcsolatos, apró részletekbe menő kérdéseikre.

\section{Szerzői információ}

Herendy Csilla, Nemzeti Közszolgálati Egyetem Államtudományi és Nemzetközi Tanulmányok Kar Közszervezési és Infotechnológiai Tanszék, Budapesti Műszaki és Gazdaságtudományi Egyetem Gazdaság- és Társadalomtudományi Kar Ergonómia és Pszichológia Tanszék https://orcid.org/0000-0003-3824-0950

Budai Balázs Benjámin, Nemzeti Közszolgálati Egyetem Államtudományi és Nemzetközi Tanulmányok Kar Közszervezési és Infotechnológiai Tanszék https://orcid.org/0000-0002-9793-4680

\section{Így hivatkozzon erre a cikkre:}

Herendy Csilla, Budai Balázs Benjámin. „Az önkormányzati honlapok szakszerű tesztelése és használhatósága közötti kapcsolat”. Információs Társadalom XXI, 1. szám (2021): 88-124.

https://dx.doi.org/10.22503/inftars.XXI.2021.1.4
A folyóiratban közölt müvek
a Creative Commons Nevezd meg! - Ne add el! - Így add tovább! 4.0
Nemzetközi Licenc feltételeinek megfelelően használhatók.




\section{The connection between the professional testing and the usability of municipality web pages}

\section{User friendly online interfaces are key to popularizing e-governance}

In 2019 the authors investigated four local municipality web pages. They aimed to determine whether web pages that underwent user testing in the planning and development stage were more user friendly. Are their e-governance pages any better? Each web page is presented using the BM ÖFFK II.1 study as well as input from designer-developers. Web pages were analyzed Nielsen's heuristics, as well as Shneiderman's golden rules. The more developed a town's IT infrastructure, the more research is done, ultimately resulting in a more user-friendly interface. The methodology applied during development leaves ample room for improvement, namely, deficient choices of research method and/or test group demographics. Another common deficiency is interface accessibility. Typically, non-Hungarian versions are sporadically available. For these reasons, municipal web pages are often below par, when compared to service provider interfaces that netizens may interact with on a daily level. When applied consequently applied, competent user research and testing would fix the issue.

Keywords: Online communication, website usability, e-government, municipal and administrative websites 


\section{Bevezetés}

Az internet szélesebb körü elterjedését követően, pontosabban a '90-es évek közepe óta a kormányzati és közigazgatási müködésben meghatározó az elektronikus csatornák egyre jelentősebb mértékű felhasználása. Az e-közigazgatási megközelítésben front-office-nak hívott felületek egyre többféle platformon egyre több és egyre fejlettebb szolgáltatást kínálnak. Emellett a kormányzat fogalma ma már nem kizárólag az államok kormányzataihoz és kormányzati szereplőihez köthető, de olyan külső szereplőkhöz is, mint például gazdasági és civil társadalmi szereplők, vagy sok esetben egyszerű állampolgárok (például lakossági kezdeményezések esetében), akik részt vesznek a kormányzásban, vagy adott esetben alakítják azt. (Betz és Kübler 2013).

A hazai közigazgatás jelentős időbeli eltolódással alkalmazkodik az internet tömeges használata révén megváltozott informálódási szokásokhoz, igényekhez, valamint az önkormányzatok többsége a törvényileg előírt tájékoztatási, információ-hozzáférési kötelezettségek teljesítését sem tudja szavatolni. Egyelőre sorvezetőt sem kapnak, így ki vannak szolgáltatva saját belső szaktudásuk és informatikai-kommunikációs partnereik tudásának (vagy ennek hiányának). A jogszabályi környezet (például Info Tv.) sem alkalmazkodott még az új csatornákhoz, így például a hivatalok tájékoztatási kötelezettsége még a web 1.0-ás gondolkodásmódot tükrözi.

A hagyományos - döntően egyirányú kommunikációt megvalósító weboldalak - használata alapértelmezettnek volt tekinthető Európa fejlettebb részein. Ezt ma már relativizálja a közösségi terek könnyebb, gyorsabb és közvetlenebb elérése. A közösségi terek előnyét - a hagyományos portálokhoz képest - Wirtz és társai - az erősebb interakció-orientáltságban, felhasználó-központúságában, a felhasználók folyamatba integrálásában, a könnyebb felület- és szolgáltatásperszonalizációban (a saját szükségletek és preferenciák szerinti felület-újrakonfigurálásban), a nagyobb felhasználói hozzáadott értékben, és az emberek csoporthoz tartozási igényéből fakadó csatlakozásban látják (Wirtz, Schilke és Ulrich 2010), a hagyományos kommunikációval szemben (Fitzsimmons 2013). A lecke fel van adva, hiszen a weboldalak felhasználóbarátsága így egyre fontosabbá válik, hogy létezésük indokolt maradjon.

Ugyanakkor nem szabad figyelmen kívül hagyni azt sem, hogy bár az új médián futó online közszolgáltatások sikerfaktora a minőség és a felhasználóbarátság, a legnagyobb társadalmi elégedettség úgy érhető el, ha a digitális tájékoztatások és szolgáltatások mellett továbbra is elérhetők bizonyos analóg szolgáltatások, mivel a komplexebb kérdésekben, témákban továbbra is fontos marad a személyes kapcsolat és közvetlen kommunikáció (BBR 2017), ugyanakkor az offline világ használatát a generációs különbségek is indokolják.

2019-re a világ lakosságának többsége internetfelhasználó volt (IWS 2019, valamint ITU 2020)). A digitális gazdaság és társadalom alapinfrastruktúrájának felületei olyan front-office részek, amelyek a közösségi érintkezések 
(social media), a kereskedelmi kapcsolatok (e-business) és a közigazgatási szolgáltatások (e-government) innovációit jelenítik meg. Azaz képet adnak az egyes alrendszerek állapotáról, a digitalizáció szintjéről, terjedéséről.

E felületek közös célja, hogy a fogyasztóorientált szolgáltatásokat kínáló weboldalak közigazgatási kontextusban „egyablakos” (azaz egy, lehetőség szerint kiszámítható, egységes felületen), illetve „többcsatornás” (bármelyik technológiával elérhető) ügyintézést nyújtsanak. A fogyasztóorientáltság nem csak a közigazgatás szolgáltatás jellegéből fakad, hanem abból a racionális megfontolásból is, hogy csak így növelhető az ilyen szolgáltatásokat igénybe vevők száma. Az pedig evidencia, hogy a hatékonyabb helyi és központi igazgatást eredményező közigazgatási reformok gyorsulása, ezen keresztül a bürokratikus akadályok csökkenését követő fokozottabb gazdasági fejlődés, a közigazgatás digitális ökoszisztémába integrálásával érhető el.

Az internetes közigazgatási jelenlét biztosítja a közigazgatás térbeli és időbeli kiterjesztését, amellyel a működési hatékonyság (és kényelem) ugrásszerűen növekszik. Ugyanakkor e kommunikációs csatorna kétirányú jellege biztosítja az állampolgárok aktívabb részvételét életük alakításában. Egy hivatal fejlettségének megállapításánál ezért beszédes, hogy hol tartanak weboldaluk fejlesztésében.

A fogyasztóorientáltság online felületek esetében azt is jelenti, hogy a közigazgatási szerv tekintetbe veszi-e a felületeit használó állampolgárok megszokásait, igényeit, gondolkodását, szükségleteit. Hatalmas kihívást jelent a közigazgatás számára az a tény, hogy az élet egyéb területein müködő online szolgáltatók egyre könnyebben és jól használható, optimálisan tervezett és fejlesztett felületeket igyekeznek létrehozni. A hazai turisztikai weboldalak például bő 15 éve rendre élenjáróak a hazai közigazgatási webes felületekhez képest (Herendy 2019; Young-Wu 2018), amelyek esetében mára már megszokottnak számít a kényelmes és gyors szállásfoglalás (az volt már 8-10 éves is), az online fizetés, a repülőjegy-foglalás és programtervezés, tehát a teljes ügyintézés. Ugyanez elmondható más szolgáltatókról is: bankokról, éttermekről, biztosítókról, nem beszélve az aktuális trendet jelentő hangalapú vezérlésről. Ez a fajta fejlettség pedig felhasználói elvárásokat is generál. A hazai közigazgatás online felületei, az elektronikus közigazgatás gyors fejlesztése igyekszik is ezeknek az igényeknek megfelelni. Azonban míg az említett utazási, banki és egyéb oldalakat kizárólag hosszú és körültekintő tervezés és felhasználói tesztelés mellett fejlesztik és tartják fenn, addig ezek a tesztelések a hazai közigazgatási szféra oldalai esetében vagy rendre elmaradnak, vagy káros fejlesztési gyakorlattal, módszertannal végzik azokat (Herendy 2015).. A közigazgatási szervek a webes fejlesztések során jellemzően nem végez(tet)nek felhasználói teszteket, vagy ha igen, akkor nagyon sok esetben rossz módszertant alkalmaznak. Például felhasználói tesztnek tekintik azt, amikor az informatikus leellenőrzi, hogy rendben átkattinthatók-e az oldalak (ami nem felhasználói teszt, hanem programozási kérdés). Más esetekben tesztelnek ugyan, de hibásan kiválasztott felhasználókkal, jellemzően a közigazgatási szerv alkalma- 
zottaival (Herendy 2015). A probléma abból adódik, hogy a készülő oldalnak a felhasználói gondolkodást és logikát kellene követnie, és nem a hivatalét. Az állampolgároknak pedig azért nehéz eligazodniuk a webes felületeken, mert azok a hivatal gondolkodását (mentális modelljét) (Herendy, 2019) tükrözik, és figyelmen kívül hagyják a usereket. Erről később átfogóbban.

Ugyanezen felhasználók azonban időközben más felületeken már megszokták, hogy az oldal tulajdonosa tekintettel van rájuk, és igyekszik könnyen megismerhető-tanulható, egyszerűen használható felületet létrehozni. A userek szívesebben is használják azokat a felületeket: az NMHH 2018-as évről szóló internethasználati felmérése ${ }^{1}$ szerint a 16 évesnél idősebb internetezők 77-72 százaléka már online tájékozódik és vásárol, 52 százalékuk online bankol, és csak 37 százalékuk használja az online közigazgatási ügyintézési lehetőségeket. Ezt az adatot torzítja (növeli) az a tény, hogy a vállalkozások kötelesek az online ügyintézést választani. Természetesen, akinek ez problémát okoz, és lehetősége adódik, rábízza az elektronikus ügyintézést a könyvelőjére.

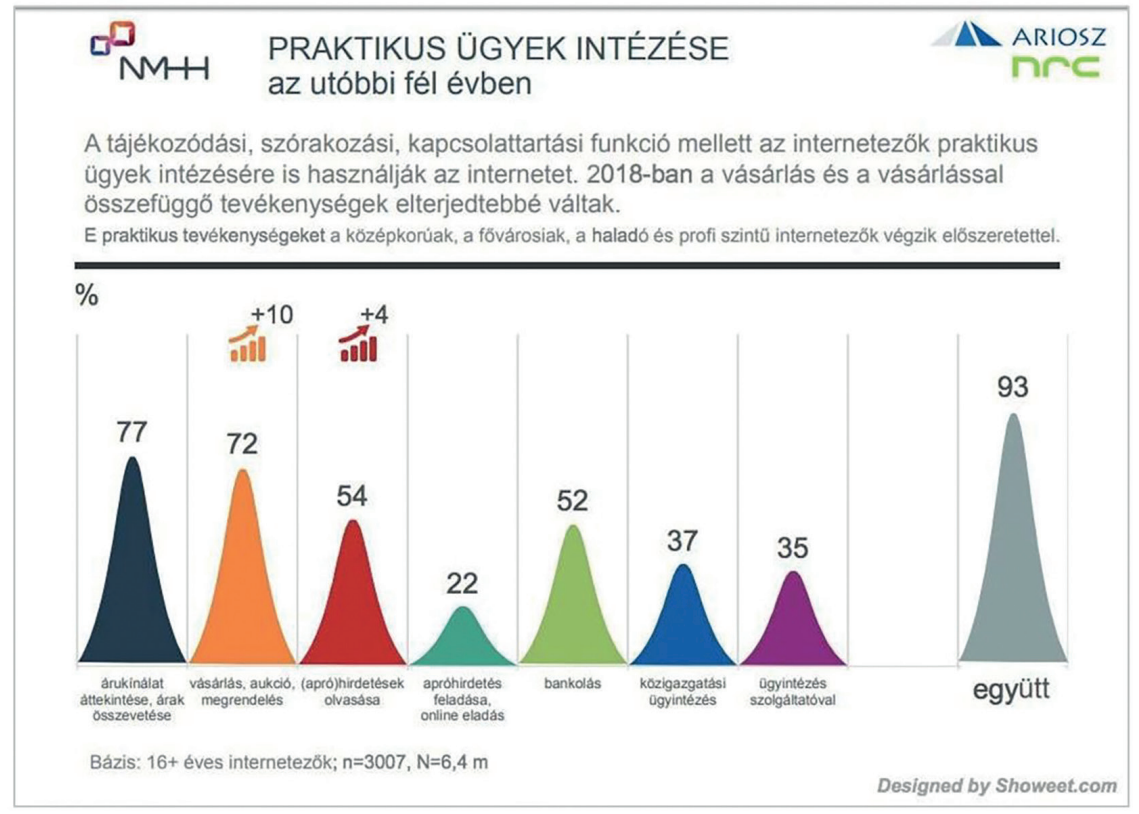

1. ábra: NMHH jelentés, 2018. Online vásárlás (72\%) vs. közigazgatási ügyintézés (37\%).

\footnotetext{
${ }^{1}$ Lásd: „A tájékozódási, szórakozási, kapcsolattartási funkció mellett az internetezők praktikus ügyek intézésére is használják az internetet. 2018-ban a vásárlás és a vásárlással összefüggő tevékenységek elterjedtebbé váltak.” A jelentés szerint a 16+ internetezők 77-72 százaléka online vásárol, 52 százalék bankol, és csak 37 százalékos a közigazgatási ügyintézés. Szerzői megjegyzés: Az adatot torzítja, hogy a vállalkozások kötelesek online ügyintézést használni. Forrás: LAKOSSÁGI INTERNETHASZNÁLAT ONLINE PIACKUTATÁS 2018 Kutatási jelentés az NMHH részére Ariosz - NRC (2018) 46. o. http://nmhh.hu/dokumentum/202180/lakossagi_internethasznalat 2018.pdf
} 
Napjainkban tehát valószínűsíthető, hogy elsősorban nem azért nem terjed sokkal jobban és gyorsabban az e-közigazgatás, mert nem kellőképpen érett a felhasználói internethasználat, vagy mert - ahogy mondani szokták - „alacsony a lakosság digitális írástudása”. Terjedne, mint ahogyan az online vásárlás, bankolás, a repülőjegy-, vagy szállásfoglalás is rohamtempóban terjed. Döntően azért élnek ezzel a lehetőséggel ritkábban és nehézkesebben az állampolgárok, mert a közigazgatási felületek jellemzően kevésbé jól használhatóak (Herendy 2008), nehezen érthető a nyelvezetük, régi megfogalmazással élve: kevésbé felhasználóbarátok. (Ezzel nem kívánjuk a digitális kompetenciaszintben, az állampolgári kompetenciaszintben mutatkozó hiányokat lebecsülni.) Igazi kihívásnak tűnik ez a helyzet közigazgatás számára, bár jó megoldások már most is láthatóak, így például a NAV e-bevallási felülete https://nav.gov.hu/nav/szja/szja vagy a mindannyiunkat igencsak pozitívan érintő Online Nyomtatványkitöltő felület, az onya.nav.gov.hu.

A közigazgatás webes jelenlétével, beleértve az eParticipációt, több írás is foglalkozik (lásd például: Shellong és Grigger 2011), és több helyen maguk a szerzők is hangsúlyozzák a felhasználók igényeinek és érdekeinek figyelembevételének fontosságát a webes fejlesztés során (Barnes és Vidgen 2004).

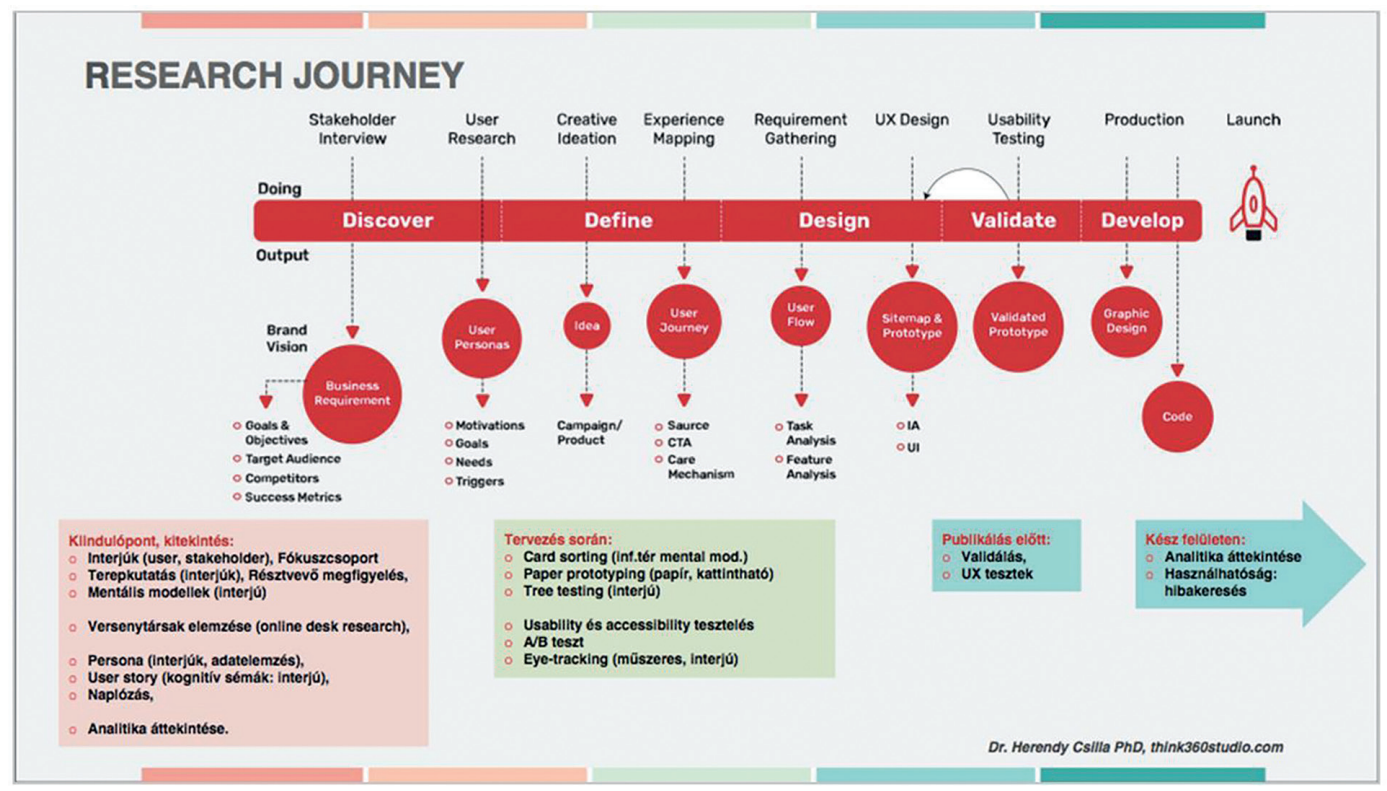

2. ábra: Research Journey, vagyis a webes fejlesztés során használható, lehetséges vizsgálati és tesztelési módszerek, idő szerint rendezve. Készítette: Herendy Csilla, a Think360 Studio alapábráját kiegészítve.

Az alábbi írásban az általános helyzetkép áttekintése után a közigazgatási szférából (hagyva most az államigazgatási felületeket) négy hazai város közigazgatási weboldalát elemezzük Jakob Nielsen dán webes használhatósági tanácsadó, és Ben Shneiderman egyetemi tanár által összeállított heuriszti- 
kák és aranyszabályok segítségével (Nielsen 1994, Scheiderman É.n.). Ezek a szabályok a UX (UX: User eXperience, felhasználói élmény) szakma egyik legfontosabb elméleti alapvetései. Mondhatjuk, hogy a legjobb weboldalak tervezése és fejlesztése során - jobb esetben - a tervezők-fejlesztők rendre igyekeznek ezeknek a szabályoknak (tudatosan vagy automatikusan) megfelelni, vagy az elvégzett sorozatos tesztelések után az elkészült felület maga természetességében felel meg azoknak. Számos egyéb kutatási és vizsgálati módszer állt volna a rendelkezésünkre (lásd: 2 . ábra), de az említett modell kínál olyan elméleti keretet, ami kellőképpen részletes és összehasonlíthatóvá teszi a felületeket.

\section{Általános helyzetkép}

Magyarországon a 2005. évi XC. törvény hatályba lépése (rendelkezéseit a 2011. évi CXII. ma is hatályos törvény inkorporálta) óta kötelező a hivatalok online jelenléte. E közel másfél évtized ellenére a Belügyminisztérium országos felmérése (ÖFFK II.) az 1000 fő alatti települések 80,5\%-ánál talált csak működő webhelyet, de még az 1000-5000 főt számláló települések esetén is 8 esetben látott weboldal nélküli hivatalt. E jelenségnek is köszönhető, hogy a Kormányzati ASP-szolgáltatást kötelezővé tették a településeknek, így 2019. január 1-től minden település számára biztosított a weboldal üzemeltetésének technikai feltétele.

Minél nagyobb költségvetéssel rendelkezik a település, annál nagyobb a diverzifikáció, annál kvalifikáltabb és specializáltabb szakértők foglalkoznak a weboldallal és annak szolgáltatásaival. Ugyancsak a település mérete határozza meg az önkormányzati információk frissítésének gyakoriságát.

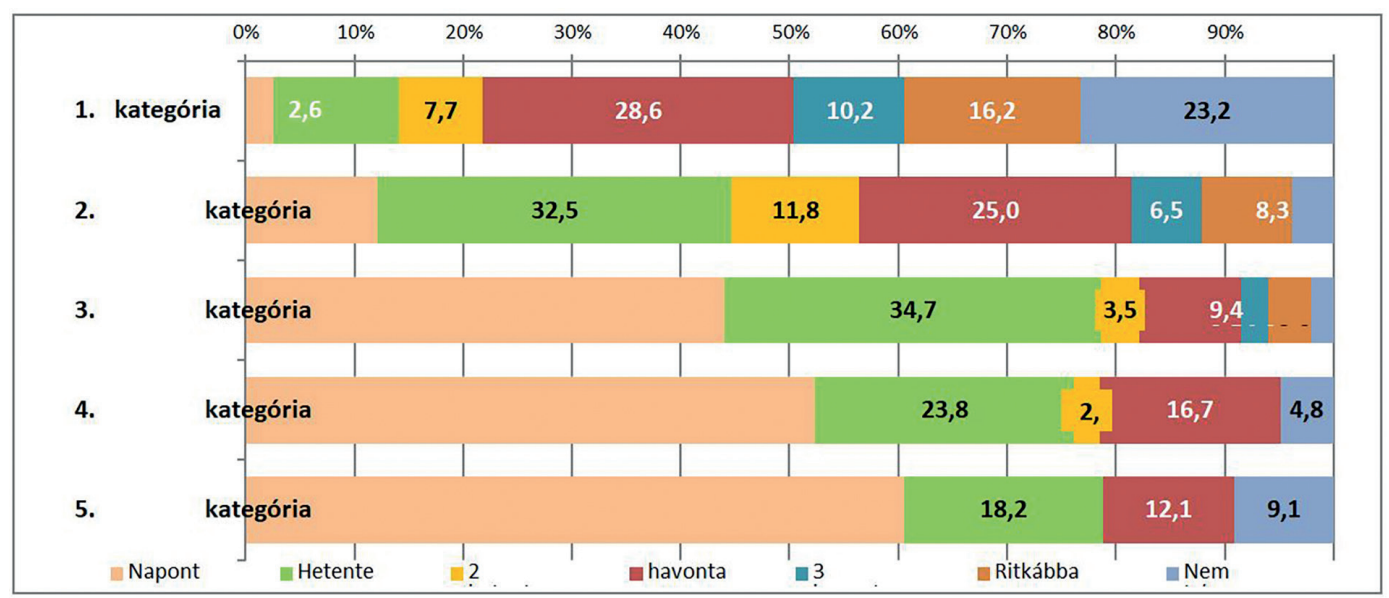

3. ábra: Az önkormányzati információk frissítésének gyakorisága a weblapokon. (Budai 2018, 62.) 
A települési webhelyek a lakosságszám emelkedésével párhuzamosan biztosítanak felületet az interakciókra (lakossági panaszokra, észrevételekre).

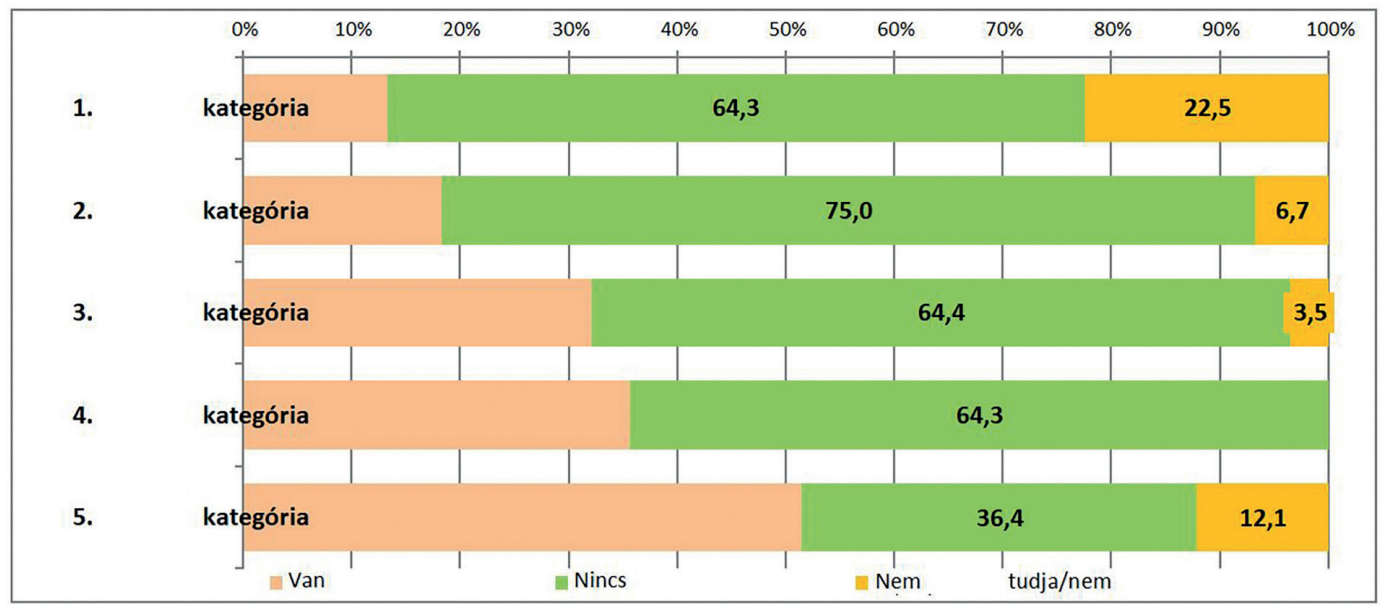

4. ábra: A lakossági észrevételek/panaszok elhelyezésének lehetősége a weblapokon. (Budai 2018, 64.)

Hasonló összefüggések mutathatók ki a közösségi webhelyeken történő megjelenéssel és ennek önkormányzati webhelybe integrálásával, illetve a kommunikáció többnyelvűségével kapcsolatban is.

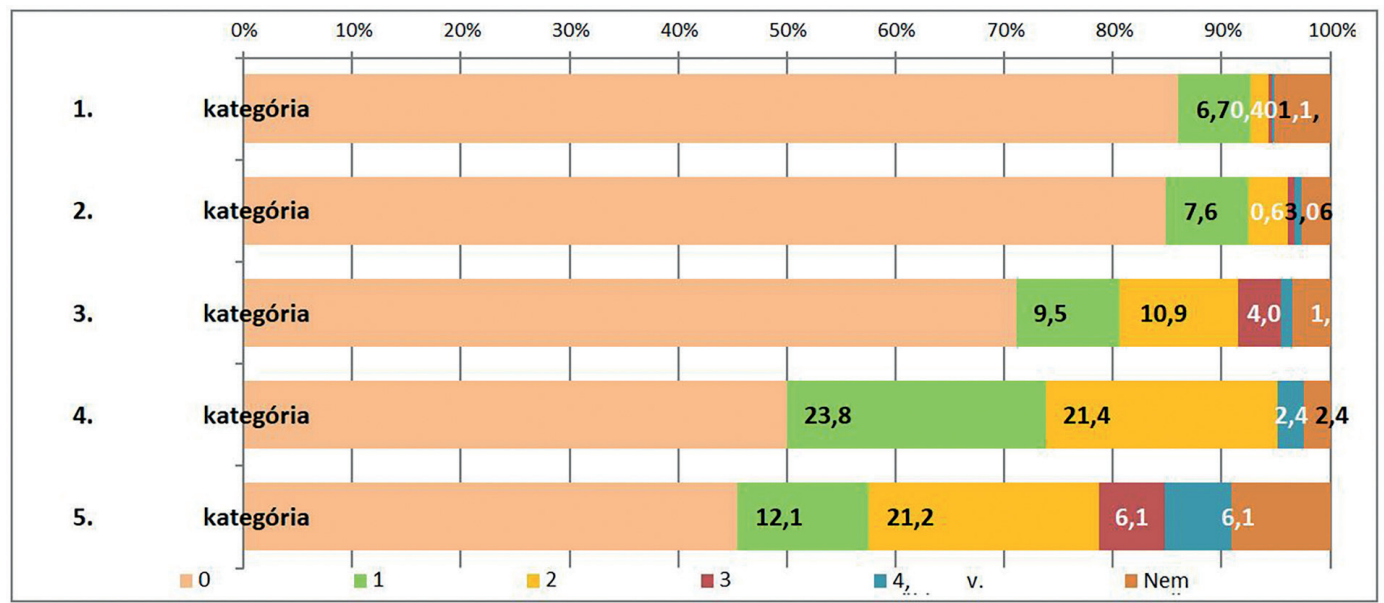

5. ábra: A települések idegen nyelveken történő online megjelenése (számok: elérhető nyelvek mennyisége). (Budai 2018, 73.)

Ugyancsak egyértelmű korreláció látszik a települések mérete és a tudás- és tartalommenedzsment szoftverek hivatali használata között, melyek a weboldalak szerkesztéséhez biztosítanak infrastruktúrát. 


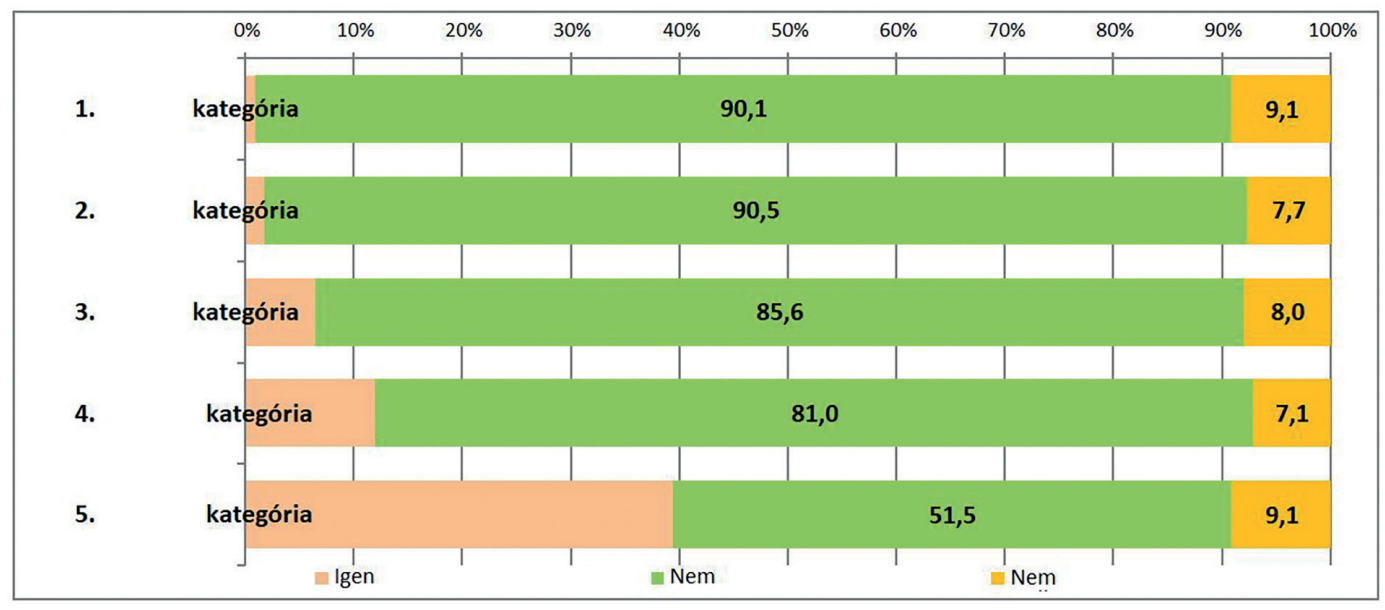

6. ábra: Tudás-, és tartalommenedzsment szoftverek használata. - jellemzően a nagyvárosok használják. (Budai 2018, 73.)

A szolgáltatások használati arányának javítása egyrészt ügyfélképzéssel, másrészt a felhasználói élmény fokozásával, a felhasználóknak inkább kedvező felületek kialakításával javítható. Előbbi még gyerekcipőben jár, csak a nagyobb városoknál érhetők tetten. Utóbbi szintúgy, bár egyre több és több pozitív példát látni.

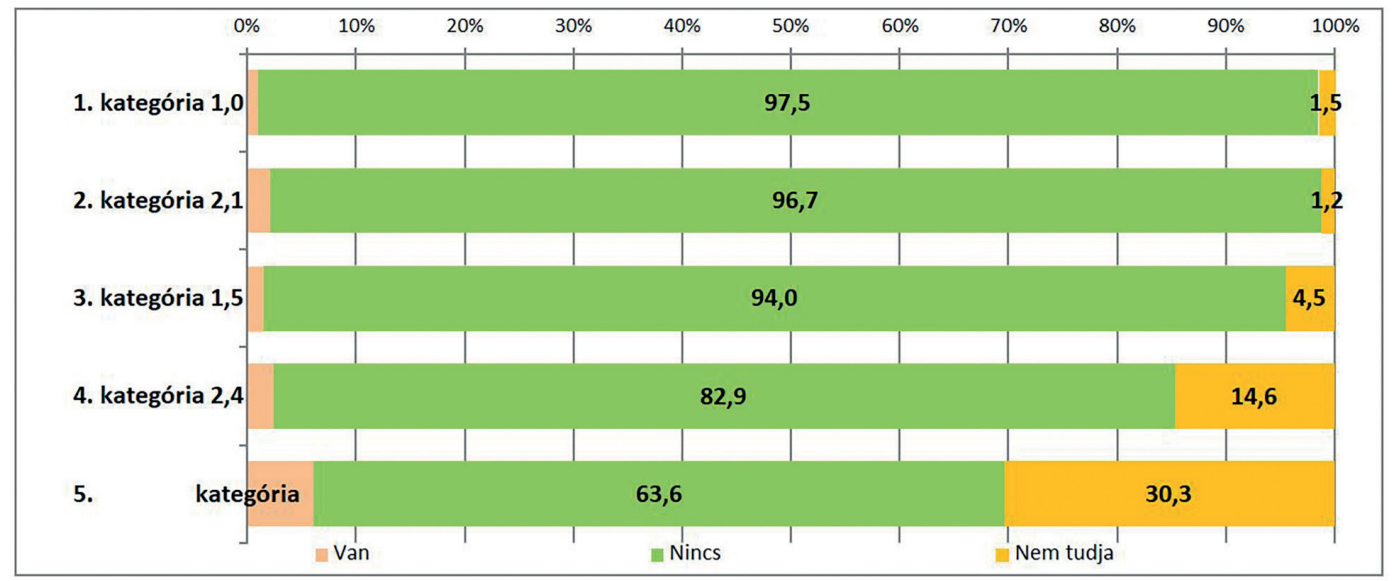

7. ábra: Települési ügyfélképzések státusza. (Budai 2018, 75.)

A hivatkozott Belügyminisztériumi kutatás az információs felületek használatával kapcsolatban, általánosságban megállapította továbbá, hogy nagyon magas a hagyományos formákra épülő kommunikációk aránya mind a hétköznapi, mind a rendkívüli közlés vonatkozásában. Ez - azon kívül, hogy költséges - lassú, a célcsoport teljes körü elérését közel sem garantálja. Bár a települési vezetők sokszor felismerik, hogy a disszemináció a virtuális térben 
könnyebben létrejön, mint egy nyomtatott termék esetében, mégis a helyi újságok elektronikus változatai nem, hiányosan vagy késve jelennek meg a települési weboldalon. Ha meg is jelennek, jellemzően letölthető PDF-ben.

A kistelepülések a weboldalak alternatíváiként használják a Facebookot: a Facebook az információszórásban kiváltja (pótolja) a weboldalt. Ennek egyik következménye, hogy a friss tartalom a Facebookra kerül, a weboldal pedig ezzel egyidejüleg gyakran elavul. A csatornák integrációja csak a nagyobb településeken, ott is csak a legritkább esetben fordul elő.

A legtöbb önkormányzati weboldal még mindig első-második generációs (HTML-alapú, statikus), információszolgáltató webhely. Friss (az ÖFFK II. felmérésnek kritériumaiban meghatározott mennyiségében és minőségében elégséges) információt a vizsgált oldalak csupán 39,2 százaléka tudott nyújtani. Még rosszabb a helyzet az e-közigazgatási szolgáltatások terén: legalább egyet az oldalak 27 százaléka kínált fel. Érdemi ügyintézési csomagot csupán a nagyobb települések képesek kínálni az állampolgáraik számára.

Az információszabadság elvárásainak való megfelelést (az információs önrendelkezési jogról és az információszabadságról szóló 2011. évi CXII. tv. mellékletében foglaltak, valamint az ehhez köthető egyéb jogszabályok szerinti) a lehetséges 252 kötelező adatból a legjobb nagyvárosok is csupán 80 százalék körüli értékeket tudtak hozni, de a leggyakoribb tartomány a 40-70 százalék közötti érték volt. Nem találtunk olyan települést, amely a jogszabályi kötelezettséget maradéktalanul betartotta.

A vizsgált oldalak közel háromnegyede semmit sem tesz a weboldalak akadálymentesítéséért. Valódi tartalmi reszponzivitást (a felhasználói preferenciák visszatükröződését) egyik esetben sem, míg technikai reszponzivitást (a felület változását attól függően, hogy milyen eszközzel böngésszük) 57,5 százalékban észleltünk. Még a modern, városi oldalak esetében is gyakran hiányzott a felhasználói élmény optimalizálása.

\section{Négy fejlett település példája}

Összességében megállapítható, hogy bár a magyar önkormányzatok egyelőre kis számban helyeznek hangsúlyt a tudatos kommunikációs tevékenységre, a jobb anyagi kondíciókkal bíró önkormányzatok ebben felülteljesítenek, és igaz ez azokra a kisebbek településekre is, ahol jelentős a turizmus. Ha a legjobb hazai megoldásokra vagyunk kíváncsiak, akkor tehát érdemes a legnagyobb városok körét vizsgálni, hiszen itt látjuk a legtöbb pozitív eltérést az előbb bemutatott átlagtól, valamint az e-közigazgatási szolgáltatások értékelhető mennyiségi és minőségi megjelenése is itt látható, elemezhető.

Jelen tanulmányunkban kiválasztottunk hármat a tíz legnépesebb város közül (Szeged, Miskolc, Szombathely). A választásakor döntő szempont volt az informatikai infrastruktúra fejlettsége. Ezt a három várost kiegészítettük egy magas adóerő-képességű közepes lakosságszámú település (Tiszaújváros) vizsgálatával. 
Elsőként az egyes oldalakat - háttér és a tervezés-fejlesztés menete alapján - mutatjuk be. Ehhez e-mailes és telefonos interjúkat készítettünk az egyes oldalak tervezéséért-fejlesztéséért felelős önkormányzati alkalmazottakkal, vállalkozókkal. A legalább egy e-mailes és telefonos interjút jellemzően két körben bonyolítottunk le településenként. Ez után arra fókuszálunk, hogy mennyiben felelnek meg a települések weboldalai az alapvető és összetettebb felhasználói igényeknek. Ennek érdekében elemeztük az oldalakon tapasztalható felhasználói élményt (azaz user experience-t, vagyis UX-et), amely során Jacob Nielsen heurisztikáit és Ben Shneiderman aranyszabályait vettük figyelembe (lásd: 7. sz. ábra). E szabályok alapvető szempontokat sorolnak fel a frusztrációmentesen használható online felületekkel kapcsolatosan. Használatuk a felhasználói élményt jól ismerő UX-tervezők és az azt vizsgáló kutatók köreiben igen elterjedt és elfogadott. Az elemzésben kitértünk az akadálymentességi szempontokra is, ebben Szántai Károly akadálymentességi szakértő volt segítségünkre.

\section{Nielsen heurisztikái}

1. Rendszer állapotának láthatósága

Mindig tudható, mi történik, a rendszer idöben visszajelzést ad

2. A rendszer és felhasználó világa találkozik

Felhasználó számára ismerös koncepciók, kifejezések, logika használata a

technológiai zsargon/struktúra helyett

3. Felhasználói szabadság és irányitás

Egyértelmü "szökési" lehetöség, visszalépés/visszavonás

4. Következetesség és konvenciók

Egységes terminológia, müködés, megjelenés; platformspecifikus tervezési minták követése

5. Hibamegelözés

A rendszer segitsen elkerülni a hibákat

6. Felidézés helyett felismerés

Memória terhelésének csökkentése: látható objektumok, opciók, instrukciók

7. Rugalmas és hatékony használat

Gyakorlott felhasználók számára a tevékenységet gyorsitó lehetöségek

8. Esztétikus és minimalista dizájn

Irreleváns, ritkán használt elemek mellözése

9. Hibakezelés

Hiba esetén a megértéshez és megoldásához segitséget nyújt a rendszer

10.Van súgó, dokumentáció

\section{Shneiderman aranyszabályok}

1. Törekedj a következetességre

Következetes terminológia, grafikai megjelenés, müködés, kezelési mód

2. Gondoskodj az univerzális használhatóságról

Pl. kezdö felhasználók számára magyarázatok, haladó felhasználók számára

röviditések, billentyüparancsok, makrók

3. Biztosits informativ visszajelzést

A felhasználó tevékenységére mindig reagáljon a rendszer

4. Egyértelmü befejezés

A tevékenységsornak legyen világos kezdete, menete és befejezése, a rendszer adjon egyértelmü visszajelzést a folyamat sikeres befejezéséröl

5. Elözd meg a hibákat

A rendszer segitsen elkerülni a hibákat

Hiba esetén: informativ, a megoldásban is segitö üzenet

6. Engedj visszavonási/visszalépési lehetőséget

Ez csökkenti a félelmet, bizonytalanságot, lehetövé teszi a kockázatmentes felderitést

7. A felhasználó kezében legyen az irányítás

A felhasználó kezdeményez, a rendszer válaszol - nem forditva

8. Ne terheld a rövid távú memóriát

A felhasználó munkamemóriája, figyelme véges - lehetöség szerint a rendszer vegye át a terheket

8. ábra: Jakob Nielsen heurisztikái és Ben Shneiderman aranyszabályai, rövid öszszefoglaló. Forrás: Fluxon.

Az egyes oldalak vizsgálata során áttekintjük a felületeket, alapvető vizuális elemeket és aloldalakat, valamint a menürendszert. Jelen írás terjedelmi korlátai miatt részletesebb elemzésre, ugyanazon feladat/ügy végigvezetésére az összes oldalon, és annak pontosabb bemutatására, a szabályoknak való megfelelés részletes elemzésére-értékelésére, vagy pontokként való értékelésére nincsen mód. Ezért az egyes oldalak tekintetében általános összefoglalót adunk, és 
csak néhány részletet emelünk ki. Az akadálymentességi szempontokra kérésünkre röviden, írásban reflektált Szántai Károly akadálymentességi szakértő.

\section{Miskolc}

\section{Háttér}

A 400 fős hivatallal működő települési önkormányzat korszerű informatikai infrastruktúrával rendelkezik. A Modern Városok programon létrejövő applikációjuk a lakosság elérését szolgálja. Ez a fejlesztés magába foglalja a városban található LED-falakat, visszacsatolást tudnak adni például egy-egy elindított szavazás állásáról (így ez alkalmas lakossági véleménykérésre is). Emellett a város egy olyan tartalomfejlesztési projektet indított, amelynek célja, hogy még strukturáltabban és informatívabban szolgáltasson, és hogy az weboldalon található információk a lakosság és az odalátogatók számára érthetően legyenek strukturálva.

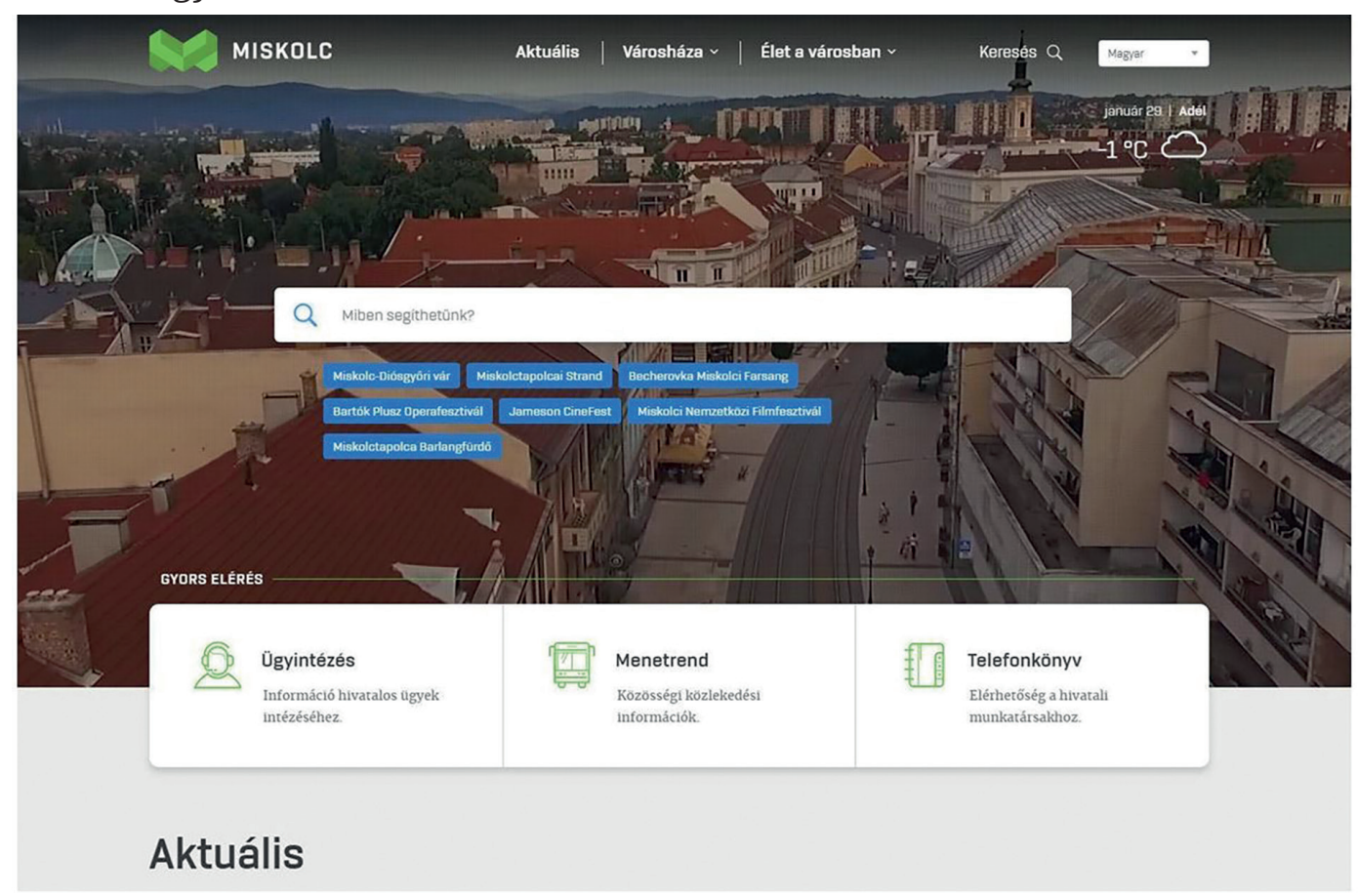

9. ábra: www.miskolc.hu (Utolsó elérés: 2019. 02.02.)

A MJV (Megyei Jogi Város) Önkormányzata és Hivatala az internetes tér használatát az átlagosnál jóval gazdagabban meríti ki, annak előnyei számukra meghatározóak, komoly jelentőségűek. A hatékony és interaktív információáramlás elősegítésére a város és a városi cégek is egyre több közösségi 
felületet használnak. Az önkormányzat az OKOS VÁROS programban kiosztott 17 ezer laptopot, amelyhez oktatás is párosult (ügyfélképzés). Az itt szerzett tudás nem csak a kommunikációban hasznosítható, hanem például lehetőséget ad az otthoni munkavégzésre is.

A http://www.miskolc.hu/ második/harmadik generációs információszolgáltató és szolgáltatásokat nyújtó webhely. A települési szolgáltatások széles skálájáról érhető el információ (például szociális-kulturális ellátórendszer, egészségügy stb.) Számos átlinkelési lehetőséggel más (több mint 70 helyi) szolgáltató honlapjára (még több információ elérését biztosítva).

$\mathrm{Az}$ oldalt igyekeztek úgy felépíteni, hogy hivatalcentrikus jellegü helyett ügyfélcentrikus legyen. Az oldal a hivatalos jelleget kifejező, egyértelmű címmel ugyan nem rendelkezik, de a nyitólap alján szereplő információk egyértelművé teszik hivatalos jellegét.

A hivatali ügyintézéshez (központi, ÁNYK-s) letölthető nyomtatványok állnak rendelkezésre, amelyekkel döntően ügyindítás (leggyakrabban kérelem) hajtható végre, és az adóügyek tekintetében 2019 májusától iForm technológiával készült (kitöltő keretprogramot nem igénylő, dinamikus tartalmú) űrlapok állnak rendelkezésre. A nem részletezett ügytípusokra a szintén központi E-papír SZEÜSZ-t ${ }^{2}$ használják. Időpontfoglalást is biztosít a honlap a Kormányablakon keresztül. Az elektronikus ügyintézés tájékoztatója nem esetenként (ügyenként), hanem egy hosszabb ügyféltájékoztató dokumentumban érhető el. ${ }^{3}$

\footnotetext{
2 (Elmondásuk szerint: „A Hivatal elektronikus ügyintézési képességeinek tervezésekor alapvető cél volt, hogy valamennyi jellemző ügytípus tekintetében rendelkezésre álljon elektronikusan kitölthető és BKSZ KEÜSZ.ön (ügyfélkapu) beküldhető nyomtatvány az ügyfelek részére. Hivatalunk ennek megfelelően mára több mint 100 db saját fejlesztésű vagy az Önkormányzat sajátosságainak megfelelően megszemélyesített űrlapot rendszeresített. Ennek ellenére a Polgármesteri Hivatal teljes ügyintézési portfólióját űrlapokkal lefedni - már csak az ügyek egyedi sajátosságai miatt is - lehetetlen vállalkozás, ezért az Eüsztv.-ben előírt kötelezettségeinek eleget téve a Polgármesteri Hivatal biztosítja az E-papír SZEÜSZ-ön (a SZEÜSZ Szabályozott Elektronikus Ügyintézési Szolgáltatás) keresztül történő beadványok fogadását is. Az E-papír szolgáltatás lényege, hogy az ügyfél KAÜ azonosítást követően szabadon összeállított beadványt (például PDF-ben) küldhet a kiválasztott címzett hivatali tárhelyére (az ügyfélkapu tárhelyből csak .KR kiterjesztésű file-ok küldhetők be közvetlenül), így azon ügyek tekintetében, ahol elektronikus nyomtatvány nem áll rendelkezésre, vagy ha az az ügy sajátossága miatt az nem alkalmazható az ügyfél a beadványát ebben a formában is eljuttathatja a Polgármesteri Hivatalhoz.” - Miskolc, Dr. Madácsi Imre kiegészítése.) Az elektronikus ügyintézés tájékoztatója nem esetenként (ügyenként), hanem egy hosszabb ügyféltájékoztató dokumentumban érhető el. (http://www.miskolc.hu/varoshaza/ugyintezes/kormanyablak-kozponti-idopontfoglalo-rendszer, http://www.miskolc.hu/sites/default/files/ egyszeru oldal/beagyazhato csatolmanyok/2019-01-14/7782/ugyfeltajekoztato.pdf)

„Az elektronikus ügyintézésre vonatkozó, önálló tájékoztató dokumentum publikálására vonatkozó kötelezettséget az Eüsztv. és végrehajtási rendelete írja elő, és lényegében meghatározza annak strukturális és tartalmi követelményeit is. Valamennyi nevesített ügytípus almenüben az ügyfelek részére a SZÜF strukturális meghatározottságával egyező ügyleírás található, amely összefoglalja az ügytípusra vonatkozó jogszabályi rendelkezések, valamint az elektronikus ügyintézési lehetőségek fontosabb ismérveit. A különálló elektronikus ügyintézési tájékoztató meglétét a NEIH kiemelten ellenőrzi, így annak alkalmazásától, és lényegi struktúrájától eltérni a Polgármesteri Hivatalnak nincs lehetősége.” - Miskolc, Dr. Madácsi Imre kiegészítése.
} 
Az oldal fejlesztése során a WCAG 2.0 Önkormányzati oldalakra vonatkozó akadálymentesítési szabványt vették figyelembe. Elmondásuk szerint a tervezés és fejlesztés során is tudatos döntés volt, hogy ezen irányelveket kövessék (Aranyosi, 2019). A tesztidőszakban a fenti cikkben említett Önkormányzati belsős tesztelésen túl a fejlesztők-tervezők is több héten át különböző felolvasó szoftverekkel tesztelték az oldalt.

Az oldal kevés látványos negatívumának egyike (az idegennyelvű változat hiánya mellett), hogy mobilalkalmazásban viszonylag lassan töltődik, Google PageSpeedInsights értéke asztali elérés esetén 78/100, mobil alkalmazás esetén 19/100. A portál optimalizálásával (például a képernyőn kívüli képek betöltésének késleltetésével vagy a képek következő generációs formátumokban történő megjelentetésével) a teljesítmény látványosan fokozható lenne. Az ügyfélkapcsolat minősége fejleszthető, nincs mód interaktív kommunikációra, hiányzik a visszacsatolás.

Miskolc Megyei Jogú Város Önkormányzata önálló Facebook-oldalt nem működtet, más közösségi médiacsatornákat sem használ. A lakossági igényt érzékelhetjük, hiszen sok oldalt találunk a felületen miskolci tartalmak köré fonódva.

- $\quad$ https://hu-hu.facebook.com/IMiskolc/

- $\quad$ https://www.facebook.com/pg/MiskolcHirei/about/?ref=page_internal

A webhely közösségi kapcsolódásának helye látszik, azonban nem funkcionál megfelelően.

A miskolc.hu tervezése, fejlesztése, tesztelése: szinte már úgy, ahogy a nagy könyvben...

2017-ben, mikor a város új arculatot kapott, a honlap is megújult. ${ }^{4} \mathrm{~A}$ teljes újratervezés célja az volt, hogy az önkormányzat a várossal kapcsolatosan felmerülö összes információt az új felületen, egy helyen tudja közzétenni. Az esztétikai ráncfelvarráson túl, egészen az alapokig igyekeztek visszanyúlni, és egy jól strukturált, célközönségi szempontjából is jól szegmentált oldalt létrehozni. A honlap fejlesztése ${ }^{5}$ során kiemelt szempont volt, hogy valamennyi célcsoport könnyedén találja meg a számára értékes információt. Ennek érdekében 2018. május 11-én nyilvános tesztidőszak indult, ahol az előző iskolc. hu oldallal együtt közel fél évig párhuzamosan futott az új oldal is. A készülő

\footnotetext{
${ }^{4}$ Előzetes megkeresésünkre a Miskolc.hu részéről Tóth Árpád online marketing referens, a fejlesztők bevonásával válaszolt, a végleges szöveget pedig Dr. Madácsi Imre e-ügyintézési koordinátor egészítette ki.

${ }^{5}$ Az oldalt az MGL Creative Kft. tervezte és fejlesztette.
} 
felületet Hotjar ${ }^{6}$ segítségével tesztelték (lásd: 10-es ábra), és itt lehetett véleményezni is. A felhasználói észrevételek és kattintások alapján hajtottak végre módosításokat rajta.

Az új oldal ezt követően, 2018 októberében váltotta fel az új oldal a korábbit. A folyamatosan beérkező visszajelzések alapján igyekeznek tökéletesíteni rajta a felhasználói élményt.

Az oldal tervezése-fejlesztése kapcsán a város részéről Tóth Árpád elmondta, hogy először egy tartalmi terv és sitemap készült el a városházán. Ez alapján átkattintható prototípust készítettek, amelyet „néhány belső felhasználó”, városházi alkalmazottak közül 20-30 fő tesztelt, végül pedig a grafikai terv készült el. A menüpontok elnevezéskor a törvénynek való megfelelés mellett fontos szempont volt, hogy a felhasználók számára érthetőek legyenek.

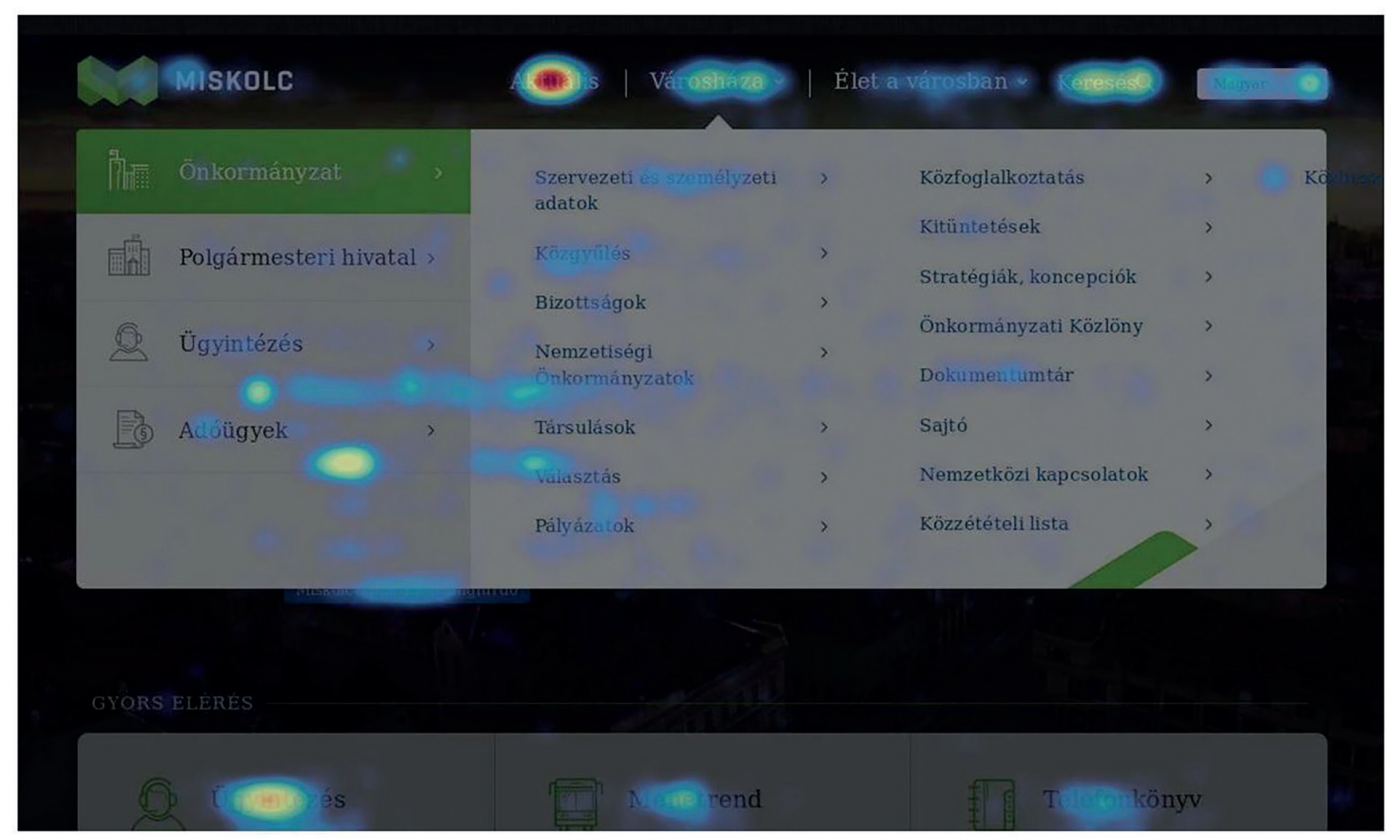

10. ábra: Miskolc.hu, Hotjar tesztelés: a legtöbbet kattintott menüpontok láthatók zölddel, sárgával és (a legnépszerübb) vörössel.

Az oldal tervezése és fejlesztése az általánosan tapasztalhatók mellett kiemelkedő. Nem véletlen, hogy 2018-ban díjat is kapott, az Év honlapja versenyen. Az oldalt a kezdetektől fogva akadálymentesnek tervezték, és azt egy városházán dolgozó, gyengénlátó alkalmazott tesztelte (Aranyosi, 2019). Hogy az oldal végül mennyire lett akadálymentes, azt csak egy alaposabb vizsgálattal és teszteléssel lehet megállapítani, de ennek elvégzésére és bemutatására jelen keretek között nincs mód. „Az oldal kódjából látható, hogy foglalkoztak

${ }^{6}$ A Hotjar azt adminisztrálja, hova kattintott a user, és nem azt, hogy hova nézett. 
valamelyest az akadálymentességgel, azonban például a főoldalon látható «hero videó» nem akadálymentes, hiszen nem lehet leállítani. Márpedig csomó felhasználó számára idegesítő az azon látható mozgás” - mondta el megkeresésünkre Szántai Károly akadálymentességi szakértő.

A miskolc.hu elemzése Nielsen heurisztikái és Shneiderman aranyszabályai alapján

Ugyan az összes alapszabálynak egyszerre nagyon nehéz megfelelni, Miskolc városának azonban túlnyomórészt sikerült: segítőkész és alapos a felület, látható, hogy a tervezők és a fejlesztők nemcsak igyekeztek megkönnyíteni a felhasználók dolgát.

A Nilsen-i heurisztikák és a Shneiderman-i aranyszabályok érvényesülését, Miskolc Megyei Jogú Város szerint tágabb kontextusban is érdemes megvizsgálni. „A honlap tervezőinek és fejlesztőinek általános szabadsága ugyanis az elektronikus ügyintézési szolgáltatások esetében sokkal kevésbé juthat érvényre az egyéb városi közszolgáltatások, vagy a turisztikai attrakciók bemutatásához képest, az alábbi körülmények miatt:

- Az elektronikus ügyintézés a közigazgatás ügyintézési szolgáltatásainak szerves része, az „csak” az eljárás módjában különbözik a „papíralapú” ügyintézéstől, a lényegi eljárási és anyagi jogi szabályok ugyanúgy meghatározzák azt, mint bármely más közigazgatási ügyintézési típust.

- „Az elektronikus ügyintézés folyamata nagymértékben - jellemzően kógens módon szabályozott (lásd Eüsztv. és végrehajtási rendelete; Ibtv. és végrehajtási rendelete).” Ez lényegében azt jelenti, hogy az elektronikus ügyintézésre kötelezett Önkormányzatok - a jogszabályi kogencia okán - sok tekintetben kényszerülnek olyan megoldások alkalmazására, amelyek nem feltétlenül segítik elő a nilseni heurisztikák és a shneidermani aranyszabályok érvényesülését.

- Az ügyfelek részéről az állandóság igénye fokozottan jelentkezik, a tapasztalatok szerint a kialakult ügyintézési struktúrák módosítása okozza az ügyfeleknek a legtöbb nehézséget a legkörültekintőbb előkészítés és ügyfél-tájékoztatás esetén is.” - mondta el a miskolci Önkormányzat részéről Dr. Madácsi Imre, Adatvédelmi Tisztviselő.

A közigazgatási felületek esetében talán a legnagyobb kihívást Nielsen 2. alapszabályának figyelembevétele jelenti, miszerint „A rendszer és felhasználó világa találkozik. Felhasználó számára ismerős koncepciók, kifejezések, logika használata a technológiai zsargon/struktúra helyett” Miskolc oldala e tekintetben is inkább segítőkész, az általánosan, könnyen elérhető szövegekben a felhasználók számára ismerős szavakat igyekeznek használni. 
Több helyen azonban problémába ütközhet az ügyfél, így például ha elektronikusan szeretne ügyet intézni. ${ }^{7}$ Hogy ezt pontosan hogyan tudja megtenni, arra részletes, letölthető tájékoztatót (PDF) talál az Ügyintézés aloldalon. Az oldal összes többi aloldatán megismert segítőkész megoldással szemben ez a terjedelmes PDF így, ebben a formájában nem mondható barátságosnak: jobban illeszkedne a felhasználó világához, az egyes felületek lennének azonnal, felhasználók számára érthető módon elérhetők. Ezzel nem segíti Nielsen 10-es szabályának megvalósulását, ami nemcsak azt jelenti, hogy legyen a felületen elérhető dokumentáció (sok oldalas PDF, amely elhelyezése egyébként a városok kötelezettsége is ${ }^{8}$ ), hanem azt is, hogy megfelelő vizuális és egyéb segítség legyen elérhető ott, ahol szükséges: mouse overre (kurzor rávitel esetén megjelenő szöveg) és egyéb, helyben elérhető, könnyen érthető magyarázatok.

Az oldalon több alapszabály sem érvényesül (Nielsen 4, 9, 10 heurisztikái). A bankkártyás fizetés egyelőre nem érhető el, ám összességében az oldal optimálisan szervezett és többnyire megfelel a hivatkozott heurisztikáknak és aranyszabályoknak. Ennek egyik alapja lehet az is, hogy az oldalt elkészülése alatt, a tervezés során többször is teszteltették. A honlap nyilvánosan elérhető tesztüzemben működött 2018 májusa és 2018 októbere között, amelyek során kapott felhasználói visszajelzéseket a honlap fejlesztése során a fejlesztők felhasználták.

Az oldalt ugyan csak hivatali alkalmazottakkal tesztelték, tehát nem a megfelelő célcsoporttal , mégis lett pozitív hatása. Ez egyébként (hivatali alkalmazottakkal teszteltetni) a tapasztalataink szerint általánosan jellemző a közigazgatásban, és a hamis konszenzus vagy egocentrikus attribúciós elfogultság miatt problémás. Erről a befejező fejezetben írunk bővebben.

\footnotetext{
7 „Miskolc Megyei Jogú Város Polgármesteri Hivatala 2018. január 1. napjától biztosítja ügyfelei részére az elektronikus ügyintézés lehetőségét valamennyi olyan ügytípus tekintetében, ahol a jogszabály személyes megjelenési kötelezettséget nem ír elő. Az Ákr. rendelkezései szerint az ügyfél által kezdeményezett ügyek kérelemre indulnak, ezért nyilvánvalóan azok a formanyomtatványok kerültek honlapunkon publikálásra, amelyek erre alkalmasak (ÁNYK keretprogram, vagy az E-önkormányzat Portál használatával). Az ügyfél által kezdeményezett ügyekben a Polgármesteri Hivatal elektronikus hitelesítéssel ellátott válasza (érdemi döntés vagy például hiánypótlás) az ügyfél (ügyfélkapu vagy cégkapu) tárhelyére (BKSZ) érkezik. Az elektronikus ügyintézés fenti módszere a Polgármesteri Hivatal által nem szabadon választott metódus azokat az Eüsztv. annak végrehajtási rendelete, és az Ákr. szabályai határozzák meg - többnyire kógens módon” - Miskolc, Dr. Madácsi Imre kiegészítése

${ }^{8}$ Az elektronikus ügyintézésre vonatkozó, önálló tájékoztató dokumentum publikálására vonatkozó kötelezettséget az Eüsztv. és végrehajtási rendelete írja elő, és lényegében meghatározza annak strukturális és tartalmi követelményeit is. Valamennyi nevesített ügytípus almenüben az ügyfelek részére a SZÜF strukturális meghatározottságával egyező ügyleírás található, amely összefoglalja az ügytípusra vonatkozó jogszabályi rendelkezések, valamint az elektronikus ügyintézési lehetőségek fontosabb ismérveit. A különálló elektronikus ügyintézési tájékoztató meglétét a NEIH kiemelten ellenőrzi, így annak alkalmazásától, és lényegi struktúrájától eltérni a Polgármesteri Hivatalnak nincs lehetősége” - Miskolc, Dr. Madácsi Imre kiegészítése.
} 


\section{Szeged}

\section{Háttér}

Szeged Megyei Jogú Város Polgármesteri Hivatalában az átlagos munkatársi létszám 350 fő. A munkavégzéshez szükséges hardverállomány és az ezt üzemeltetni képes munkatársi állomány kompetenciája, a Bevezetőben hivatkozott BM kutatás szerint megfelelő. A tudás- és tartalommenedzsment szoftvereket használók száma 61 fő, mely bíztató tartalomgazdálkodást feltételez az internetes kommunikációk során.

A település több honlapot üzemeltet: www.szegedvaros.hu és a www.szeged.hu- t, az utóbbi inkább hírportál. Ezenkívül több városi intézménynek van saját holnapja. A www.szegedvaros.hu honlap csoportosítva szólítja meg a célcsoportokat például lakosok, turisták, befektetők.

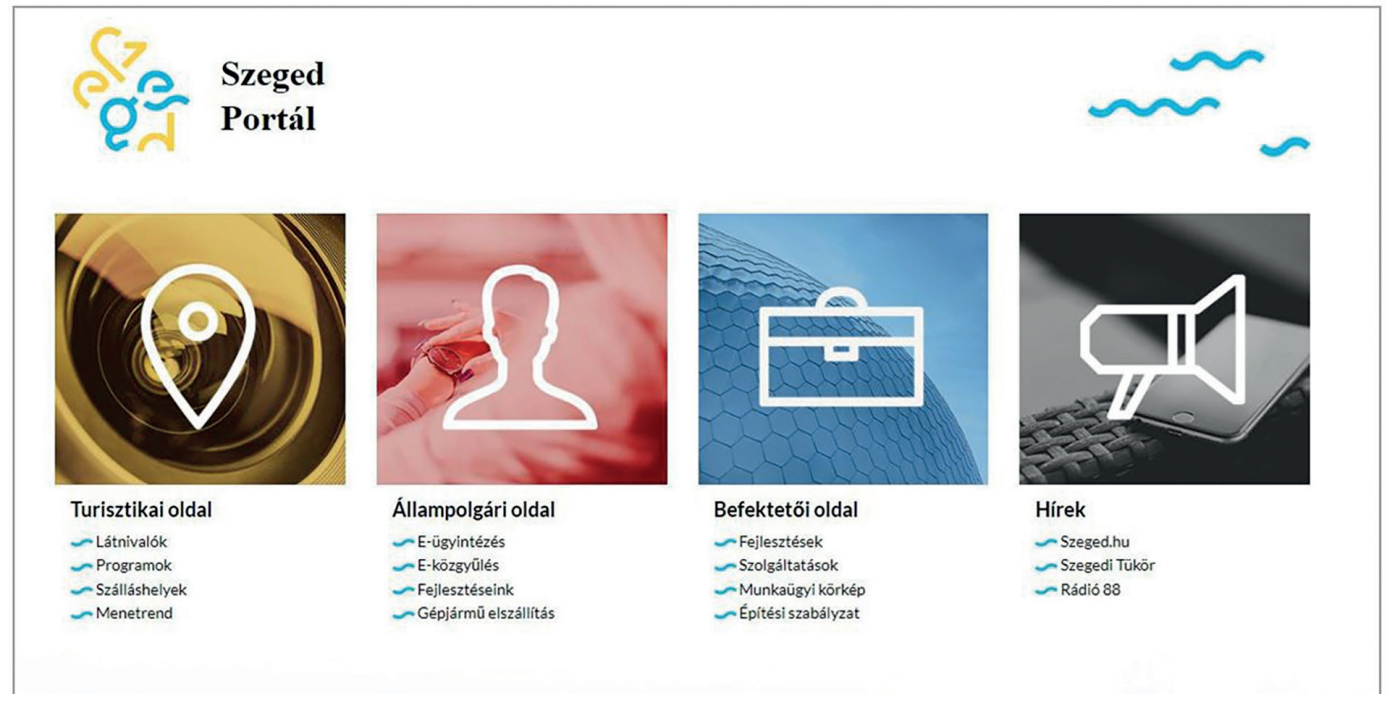

11. ábra: www.szegedvaros.hu (Utolsó elérés: 2019. 02. 02.)

A település portálja második generációs, információs portál. Tematikájában, felépítésében is azt a célt szolgálja, hogy minél jobban kiszolgálja a látogatók információs igényét. A fejlécben - kevésbé könnyen észrevehetően - érhetők el a közösségi felületek. A szolgáltatások propagálása megfelelő, az oldalról elérhető közszolgáltatások száma magas. Az oldalon a településre vonatkozó adatok teljesek, a közérdekű információk mennyisége megfelelő. A hírek frissek, mennyiségük kielégítő.

A keresőablak a keresés után több oldalnyi strukturálatlan találatot ad ki, és a pontosítását, szűkítését később már nem ajánlja fel, így az olykor nagy találati eredmény csak új kereséssel szűkíthető Az ügyfélkapcsolat minősége fejleszthető, az interaktív kommunikációra csak bizonyos témákban ad módot. 
A szervezeti egységek, vezetők és ügyintézők telefonszámos és e-mailes elérhetőséggel is szerepelnek. A települési képviselők e-mailben kereshetők fel. A tájékozódást hasznos linkek segítik, tematikus csoportosításban. Az ügyfélfogadás rendje elérhető, a képviselőtestület névsora megtalálható. A képviselők beosztása és elérhetősége adott. A hivatali ügyintézéshez letölthető nyomtatványok rendelkezésre állnak, sok ügyleírás szerepel.

E-ügyintézés az online űrlapok segítségével a regisztrációt követően használható.

Az időpontfoglalás a weblapon nem biztosított.

A felolvasható megjelenést az oldal nem támogatja, változtatható betűméret funkció van. Mozgássérülteknek, koordinációs problémákkal küzdőknek: egér kiváltása, hangvezérlő interfész, tetszőleges várakozási idő az interakciók során nem került beépítésre.

A Hivatal kommunikációjában nem kezeli kiemelten a hátrányos helyzetű csoportokat.

A https://www.szegedvaros.hu/ információszolgáltató webhely. A látogató elegendő információt szerezhet a szolgáltatásokról (angol nyelven wz azonban csak a turisztikai információkra korlátozódik). A települési szolgáltatások széles skálájáról érhető el információ (például szociális-kulturális ellátórendszer, egészségügy, közrend stb.), igaz, sok esetben üres, vagy hiányos oldalakkal találkozunk. Számos átlinkelési lehetőség biztosított a helyi szolgáltatók honlapjára, ahonnan még több információt nyerhetünk ki. E-közigazgatási szolgáltatásként letölthető formanyomtatványok lelhetők fel (bár azok nem tematikusan, hanem alfabetikus sorrendben követik egymást.) Elérhető továbbá a szegedi elektronikus adózási rendszer is, melyhez elektronikus formanyomtatványok és számlaegyenleg lekérdezési funkció is csatlakozik.

\section{A szegedvaros.hu tervezése, fejlesztése, tesztelése}

Szegednek 2003 januárjától van saját weboldala. ${ }^{9}$ Korábban már létezett ugyan a szeged.hu oldal, de az nem a város tulajdonában, hanem magánkézben volt. Ez a felület most (2019 nyara) a Hírek linkre kattintva érhető el.

A jelenleg elérhető verziót 2015-ben kezdték el tervezni és 2016 májusban indult el. Az oldalon az e-közigazgatási funkciók 2006 júliusától érhetők el. Ez és a város weboldala két külön felületen található, mindkettőt külön is tervezték. Elektronikusan nem lehet ügyet intézni a felületen, erről csak „információt tudnak szerezni az állampolgárok és bizonyos esetekben nyomtatványokat tudnak letölteni és otthon kitölteni. A dokumentumok PDF formátumúak”mondta el a felülettel kapcsolatban Sándor József.

\footnotetext{
${ }^{9}$ Szeged városának fejlesztésével kapcsolatos kérdéseinkre Sándor József informatikai csoportvezető válaszolt.
} 
Az oldal létrehozásának célja a szegedi állampolgárok tájékoztatása volt, célcsoportja minden felnőtt magyar állampolgár. A fejlesztés során nem vettek figyelembe akadálymentességi szempontokat, és idegennyelvű verzió nem készült.

Az oldal tervezése során a tartalom volt az elsődleges szempont, és „a grafika sokkal többször változott, mint az oldal struktúrája. Minden tartalmi változást egy hivatalon belüli egyeztetés előzött meg, az Ügyfélszolgálatunkra beérkezett visszajelzéseket is figyelembe véve. De mindenképpen fontos a jogszabályi háttér szem előtt tartása, ami az utóbbi időkben nem kevés mértékben változott”. A navigációra nem készült külön terv, a menüpontok elnevezésekor „a jogszabályokat vették figyelembe (...).”

Az oldal fejlesztése során nem kérdezték meg a célcsoport tagjait, csak „kollegákat vontunk be a szakirodáktól”. Az oldalt nem vetették alá felhasználói tesztelésnek, csak „informatikailag és szakmailag volt tesztelve” (ez a kettő nem ugyanaz).

Az e-közigazgatással kapcsolatos felületen az elérhető funkciók sorrendjét sem tesztelték, így azokat találomra sorrendezik, és nincsenek tekintettel arra sem, hogy mely szolgáltatást hányan vesznek igénybe. A tervezők sem az oldal kialakításakor, sem pedig a közigazgatási funkció sorrendezésekor nem voltak tekintettel a korábbi analitikai adatokra.

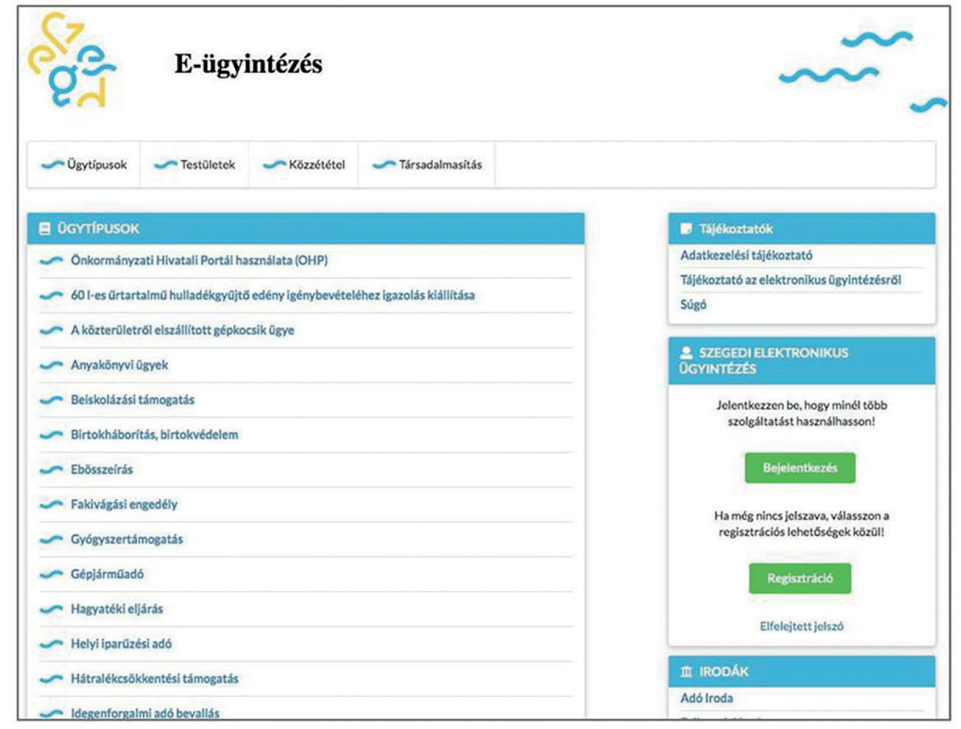

12. ábra: Szegedvaros.hu e-ügyintézési felülete (Utolsó letöltés: 2019. július 22.)

A fejlesztés során a tervezésbe nem vonták be a felhasználókat, de elemezték az oldalon 2006 óta elérhető online kérdőív adatait. A kérdőív egy korábbi, papíralapú kérdéssor online változata, 2006 óta nem aktualizálták és 2016 óta nem elemezték az onnan beérkező válaszokat sem. A kérdőív javítása, aktualizálása évek óta aktuális kérdés. 
Felhasználói - vélhetően sporadikus és változó minőségű - visszajelzéseket is ezen űrlapon keresztül, és az Ügyfélszolgálat segítségével kapnak. Az oldal tulajdonosai tisztában vannak azzal is, hogy az oldal hibája a többnyelvüség és az online ügyintézés hiánya, ezek fejlesztése évek óta téma.

A szegedvaros.hu és az eservices.szeged.eu oldalak elemzése Nielsen heurisztikái és Shneiderman aranyszabályai segítségével

A szegedvaros.hu oldalra érkezve négyféle felületet érhet el a felhasználó, desktop és mobil változatban is. Az oldalról elérhető aloldalak stílusukban, forma- és színvilágukban teljesen eltérőek. Ezek közé, a „Hírek” képre kattintva érhető el a szeged.hu oldal is és az

„Állampolgári oldal”-ra kattintva pedig a helyi hivatalos híreket tartalmazó felület. Az e- ügyintézésre külön, direkt link vezet. Ugyanezt a felületet különböző aloldalakról különböző nevekre „ügyintézés” „e-ügyintézés” kattintva érhetjük el.

Zavaró tényező, hogy az egyes oldalak se szín- és formavilágukban, se tartalomfelépítési rendszerük (menüstruktúra jellege és annak megjelenítése) tekintetében nem egységesek. Ezáltal, a teljes felületet összességében tekintve nem valósul meg Shneiderman 1. aranyszabálya, miszerint „Törekedj a következetességre. Következetes terminológia, grafikai megjelenés, működés, kezelési mód”.

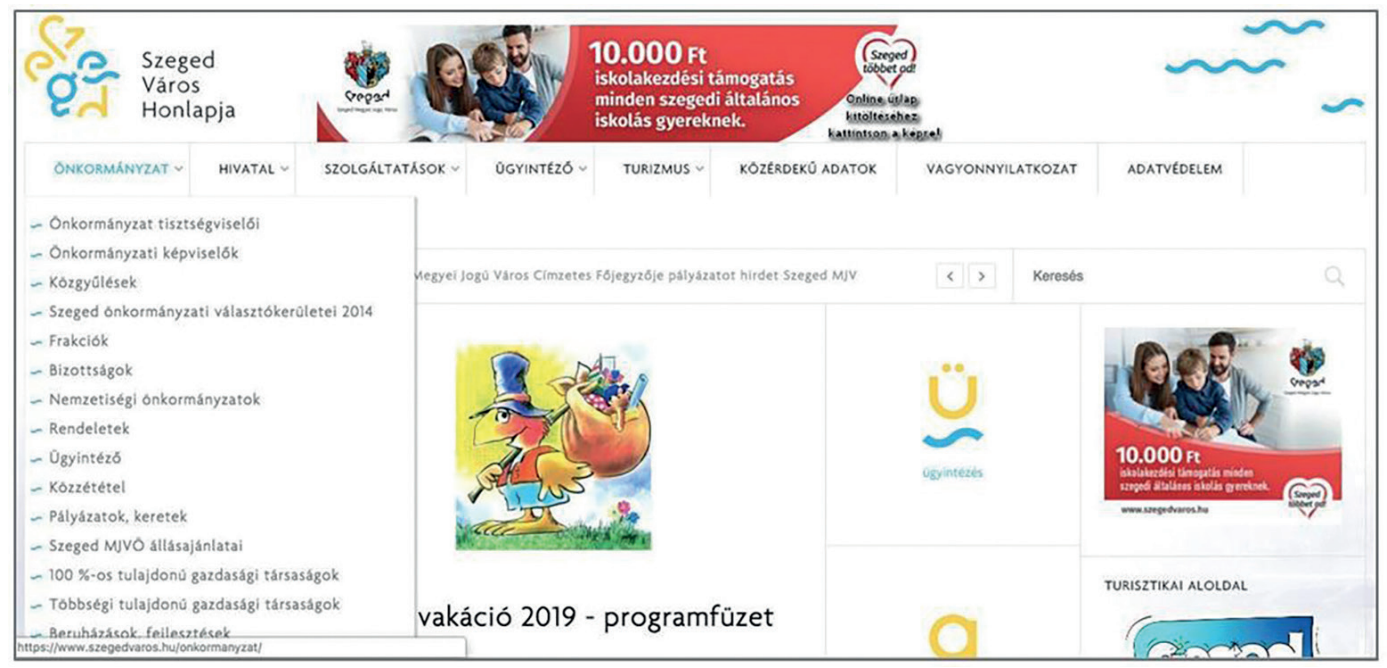

13. ábra: Akkora az oldalon a legördülő menü, hogy egy átlagos monitor (1920x1080 pixel) nem tudja megjeleníteni. (Utolsó letöltés: 2019. július 22.)

Szeged város honlapján az azonnal látható leginkább problémás részlet, hogy a legördülő menü olyan hatalmas, hogy nem látható teljességében, így 
az alul elhelyezkedő linkek nem is érhetők el, már egy közepes felbontású monitoron sem. Mobilon csak hosszas görgetéssel érhető el minden menüpont, a képernyő alsó felén görgetve.

Amennyiben elrontottunk valamit és vissza szeretnénk lépni a főoldalra, a bal felső sarokba kattintva nem Szeged város honlapjára, hanem a kezdő gyüjtőoldalra jutunk. Ez alapvetően ellentmond azzal, amit az online felületeken megszoktunk visszalépés esetén.

Az Önkormányzati elektronikus ügyintézés oldalon több, központi közigazgatási videó is elérhető, amelyeken felhívják a figyelmet arra, hogy milyen ügyeket lehet már online elintézni. A videók azt nem mutatták be, hogy az egyes ügyeket hogyan intézzük, csak az adott funkció elérhetőségéről tájékoztatnak. Kevésbé szerencsés, hogy csak a „mit” mutatják, és a „hogyan”- t nem. Az ügyintézéssel kapcsolatban részletes tájékoztató sem érhető el.

A szegedvaros.hu és az eservices.szeged.eu oldalak felületének nyelvezete nem egységes (ügyintézés, e-ügyintézés), a rendszer sok esetben nem jelzi egyértelműen, hogy merre tartózkodik éppen a felhasználó. Így nem érvényesül Shneiderman 1-es és Nielsen 1-es számú heurisztikája sem. Az oldal nyelvezete egyértelműen a közigazgatásét tükrözi, a „Közzététel”, „Társadalmasítás” stb. olyan menüpontok, amelyek érthetőbbek lennének például mouse over segítséggel vagy egyszerübb, közérthetőbb fogalmazással. A felület mind szóhasználatában, mind felépítésében a hivatal logikáját tükrözi, de még abban sem mindig egyértelmű. Erre példa, hogy ugyanaz a funkció más-más megnevezéssel többféle linkről érhető el, például „Ügyintézés”, „e-ügyintézés”. A felületen az alábbi szabályok nem érvényesülnek: Nielsen 2, 3, 4, 8, 10 és Shneiderman 1.

Nincsen lehetőség a felületen a visszalépésre és nem érvényesülnek a platformspecifikus tervezési minták sem.

Az oldalnak nincsen más nyelven is elérhető verziója, csak a magyar, emellett az akadálymentesített felület sem felel meg az azzal kapcsolatos ISO-szabályoknak. ${ }^{10}$

Elemzésünk nem részletes, egy kutató végezte azt el, és semmiképpen sem teljes körü, így csak a legalapvetőbb szempontokat taglalja igen röviden. Nem néztük át tehát a teljes felületet, de a jelzett problémák már néhány aloldalt áttekintve is vissza-visszatérők voltak.

Látható, hogy Szeged önkormányzati és e-ügyintézési felülete a jelzett aranyszabályoknak és heurisztikáknak a legtöbb helyen nem felel meg, de ezeket a problémákat, összezavaró tényezőket már egy egyszerűbb, alacsony résztvevői számmal ${ }^{11}$ elvégzett felhasználói teszteléssel is ki lehetett volna szürni, vagy legalábbis a mennyiségüket csökkenteni, az irányelveket pedig a tervezés során megismerni, áttekinteni, majd alkalmazni.

\footnotetext{
${ }^{10}$ Bővebben lásd: Szántai Károly: Nem az akadálymentes verzió a megoldás (2011, 2013) https://www.akadalymentesweb.hu/2011/08/nem-az-akadalymentes-verzio-a-megoldas/

${ }^{11}$ Jakob Nielsen szerint már 5-8 résztvevővel s érdemes tesztelni, bővebben: Jakob Nielsen, 2000.
} 


\section{Szombathely}

\section{Háttér}

Szombathely Megyei Jogú Város Polgármesteri Hivatalában az átlagos munkatársi létszám 233 fő. A Hivatal számítógépes környezetéről elmondható, hogy a munkaállomások kimagaslóan jó minőségűek és a munkavégzéshez szükséges informatikai környezet is kiemelkedő (max. 2 éves). A munkaállomásokat folyamatosan cserélik vagy újítják fel annak érdekében, hogy a legkorszerűbb környezetet tudjanak biztosítani a felhasználóknak. A jelenlegi portáluk fejlesztését megelőzően városi szinten végeztek felméréseket a lakosság körében, és ezen felmérési eredmények feldolgozásával készítették el 2014-2015 évben.

A városi portál 2009, 2010, 2014 és 2015 évben az Év honlapja díjat is elnyerte, valamint a szombathelypont 2014-ben az év applikációja díjat kapta. A felmérések, kutatások eredményeként a fejlesztés kezdetekor különválasztották az önkormány/hivatal, valamint a város életével összefüggő lakossági, turisztikai szolgáltatásokat. Az önkormányzat/hivatal kapcsán fontos információk a szombathely.hu felületen, míg az egyéb Szombathelyt érintő (turisztikai látnivalók, gasztronómiai, szállás, sport, szabadidő, hasznos) információk a szombathelypont.hu és ennek a mobilapplikációs felületén érhetők el.

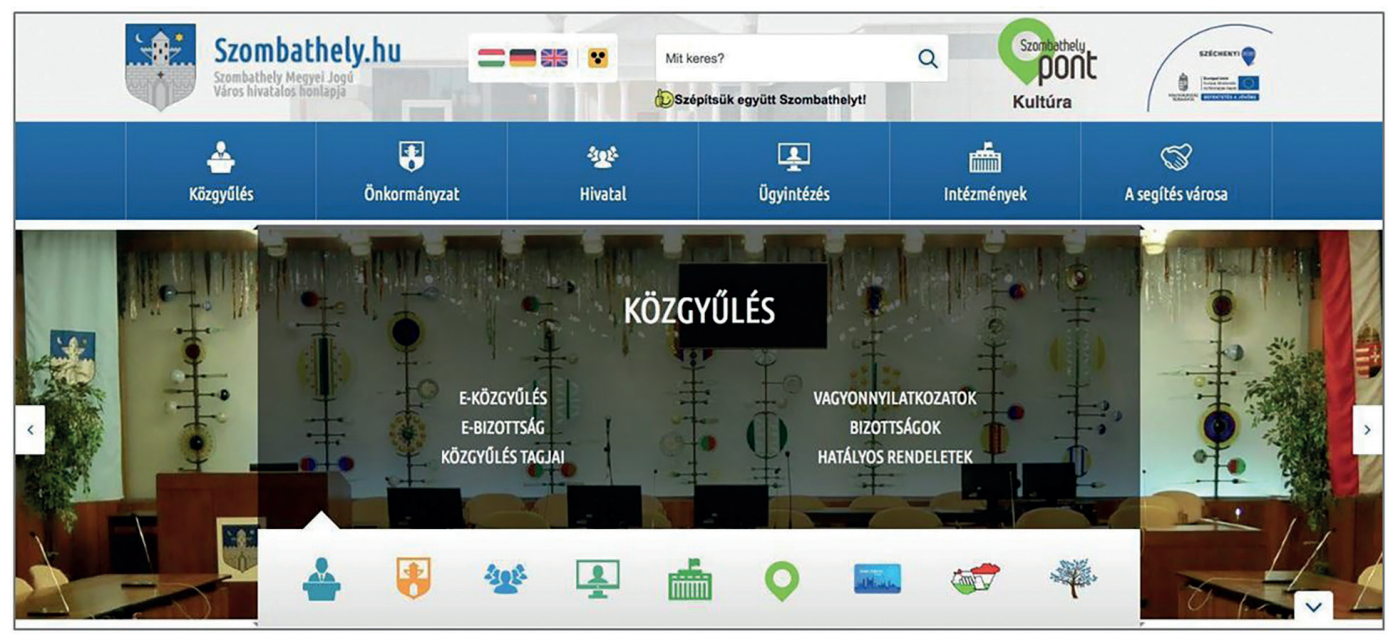

14. ábra: www.szombathely.hu (Utolsó elérés: 2019 február 2.)

A http://www.szombathely.hu/ információszolgáltató webhely. A települési szolgáltatások széles skálájáról érhető el információ (például szociális-kulturális ellátórendszer, egészségügy, közrend stb.). A hírek frissek, mennyiségük kielégítő. A településre vonatkozó adatok teljesek. A kezdőoldal középpontjában a hírek, programok, aktualitások állnak. 
A szombathely.hu hivatalos jelleget kifejező, egyértelmű címmel rendelkezik.

A testületi ülésekről az „e-közgyülés” menüponton keresztül érhetők el releváns dokumentum: rendeletek, határozatok, jegyzőkönyvek. Az önkormányzat nagyszámú stratégiai dokumentumai is rendelkezésre állnak.

A közérdekű adatok külön menüpontban találhatók meg, a menüpontra viszonylag könnyen rábukkanhatunk. A szombathely.hu oldalon angol és német nyelven csak a köszöntő érhető el, a többi tartalom, mivel önkormányzat/ hivatal információkat tartalmaz alapvetően csak magyar nyelven.

A honlapról a települési Facebook-oldalra linkelhetünk (a Facebook-oldal nincs a honlapba integrálva).

$\mathrm{Az}$ oldal a felolvasható megjelenést nem támogatja, de van változtatható betűméret, színbeállítási lehetőség, navigációs segítség funkció a mozgássérülteknek, koordinációs problémákkal küzdőknek. Egér kiváltása, hangvezérlő interfész, tetszőleges várakozási idő az interakciók során nem került beépítésre. „Fogyatékos-barát” technikai megoldásokat alkalmaznak, melyeket a Vas Megyei Vakok és Gyengénlátók Egyesületének szakmai közreműködésével dolgoztak ki. Sárga-fekete megoldás elérhető az oldalon, kialakításához helyi szakembereket kerestek meg, és az általuk kiválasztott résztvevőkkel tesztelték azt.

A Hivatal kommunikációjában kiemelten kezeli a hátrányos helyzetű csoportokat. A portál akadálymentes változatának létrehozásba bevonták a Vas Megyei Vakok és Gyengénlátók Egyesületét. A szombathely.hu honlapon ugyanakkor a WCAG akadálymentességi vizsgálatok nagy hibaszámot mutatnak, valószínűleg a felolvasó szoftverek és egyéb akadálymentesítést végző eszközök nehezen tudják a honlapot kezelni.

A hivatali ügyintézéshez letölthető nyomtatványok rendelkezésre állnak, sok ügyleírás is szerepel. E-ügyintézést ügyfélkapu keresztül, ÁNYK program igénybevételével és a letölthető nyomtatványok segítségével végezhetünk. Időpontfoglalás az egyes szervezeti egységnél megadott telefonos egyeztetéssel lehetséges. Amennyiben rendelkezünk audiovizuális eszközökkel (mikrofon, webkamera, hangszóró) és Skype-fiókkal, az ügyintézőnktől közvetlen módon kérhetünk felvilágosítást, többféle témakörökben. Számos ügymenettípus érhető el elektronikus úton a lakosság és a vállalkozások számára, így elektronikus ügyintézés is több területen valósulhat meg.

\section{A sombathely.hu tervezése, fejlesztése}

Szombathely weboldala 1996 óta létezik. Az elmúlt évtizedekben nagyon sok átalakításon ment keresztül, a jelenlegi portálrendszer tervezését 2014-ben kezdték el. Ennek koncepciója az volt, hogy különválasztották egymástól a közigazgatással összefüggő területeket és a várost érintő egyéb részeket (turisztika, gasztronómia, kultúra, sport stb.). A két rendszer átjárhatósága alapelvárás volt a város részéről, ennek tükrében fejlesztették a szombathely.hu és 
a szombathelypont.hu oldalakat. Ennek értelmében a szombathely.hu oldalra kattintva alapértelmezésként a közigazgatással összefüggő elemeket találhatjuk meg, azonban a „szombathelypont” banneren keresztül eljuthatunk a másik nagy területünkre, amely a város életével összefüggő tartalmakra koncentrál. A SzombathelyPont mobilapplikációt kimondottan a városban élők és turisztikai célból oda érkező látogatók érdekében fejlesztették ki, amely több olyan megoldást is takar, ami segíti a tájékozódást a városban, és általa bárki közvetlenül, gyorsan tud naprakész információhoz jutni.

Az oldal tervezésével, fejlesztésével kapcsolatosan Keringer Zsolt osztályvezető állt a rendelkezésünkre, az ő információi alapján mutatjuk be az oldal tervezését, fejlesztését.

A rendszer kialakításánál elsődlegesen a publikálandó adathalmazt és a leendő szolgáltatások körének felmérését végezték el, és ennek megfelelően alakították ki a fejlesztési alapelveket és tartalmi elemeket. A grafikát tekintve elsődleges céljuk volt, hogy letisztult és könnyen értelmezhető felületet hozzanak létre. A navigáció esetében a városvezetés jól kezelhető és átlátható felületet szeretett volna látni. Az oldal tulajdonosainak elmondása szerint a látogatottságot saját fejlesztésű programmal nézik, és ezzel kérnek le statisztikákat.

„A rendszer fejlesztése során egy szűk szakmai gárdát alakítottunk ki, ahol az informatikai szakemberek mellett az adatbázis gazdák is bevonásra kerültek, valamint a grafikus tervezői csapat is részt vett a koncepció és a gyakorlati kivitelezésben.(...) „A rendszer bevezetése előtt természetesen teszteléseket is elvégeztünk (...), amelyek végrehajtásába alapvetően a szakterületen dolgozó kollégákból (területenként 2-3 fö) választottuk azokat, akik a fejlesztés során is közremüködtek a felület kialakításában” - mondta el Keringer Zsolt. A honlapon szereplő közigazgatási szolgáltatások kiválasztása tekintetében lakossági véleményeket is begyüjtöttek, telefonos interjú és online kérdőív segítségével.

A felületet igyekeznek állandóan naprakészen tartani. Ezen keresztül kapnak rendszeresen észrevételeket is a felhasználóktól, amelyek egy részét figyelembe veszik és beépítik a fejlesztés során. A tervezés során nem volt lehetőség kutatásokra.

A szombathely.hu elemzése Nielsen heurisztikái és Shneiderman aranyszabályai alapján

Az egyes aloldalak színvilágukban és tipográfiájukban is komplett, jórészt egységes képet mutatnak, és a vizsgált heurisztikáknak, néhány kivételtől eltekintve alapvetően megfelelnek.

Az ügyfelek számára a legtöbb infromáció az Ügyéntézés aloldalon érhető el.

Szükséges volt a kötelező jogszabályok, bankszámlaszámok felsorolása, illetve az e-Papír és az elektronikus ügyintézésről rövid tájékoztatás adása. Az oldal tulajdonosainak elmondása szerint figyelembe kellett venni, hogy „,azok 
az ügyfelek, akik nem képzettek informatikailag, is értsék és megtalálják a keresett ügyeket”. Elmondásuk szerint nem okoz gondot az ügyfelek számára a nyomtatványok megtalálása, kiválasztása. Ezt nem tudták sem tesztelésre, sem felhasználói visszajelzésekre alapozni.

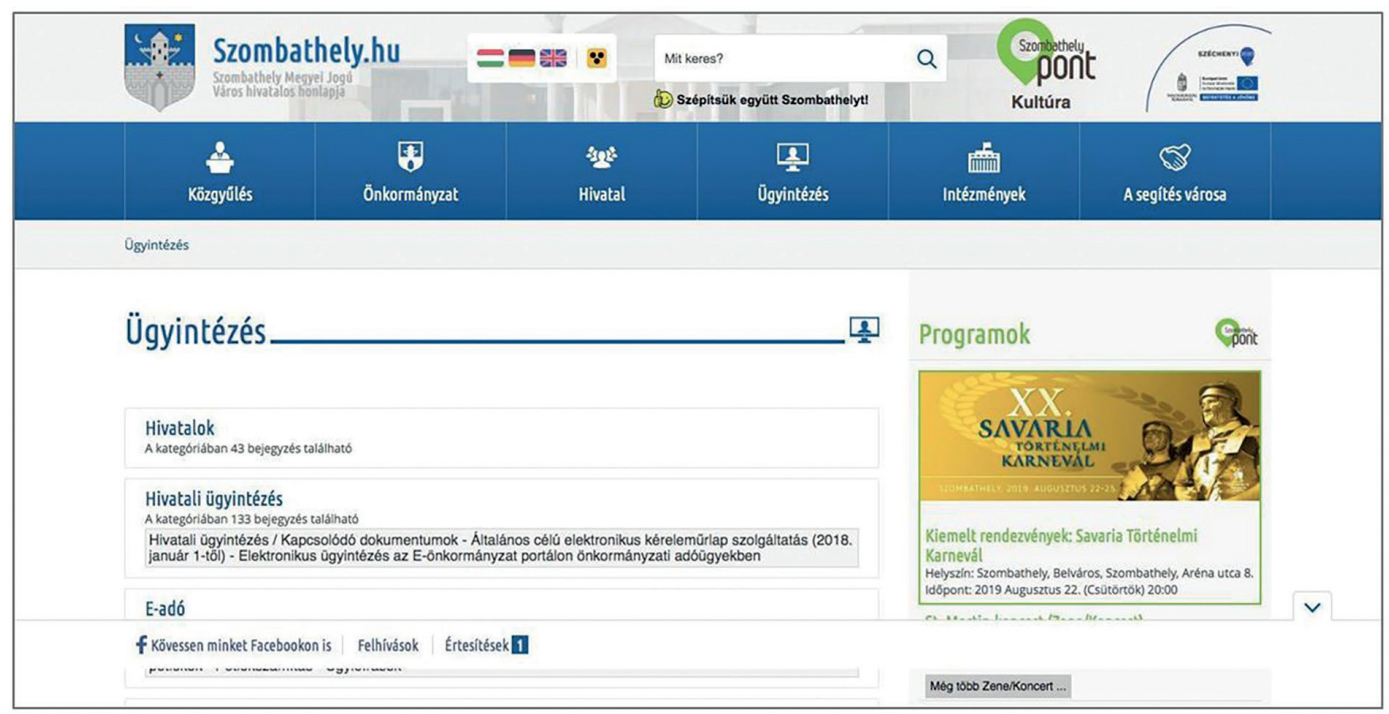

15. ábra: Hivatali ügyintézés aloldal. (Letöltés: 2019. augusztus 1.)

Az Ügyintézés oldalról elérhető Elektronikus ügyintézés link oldalán a tényleges tartalom (önkormányzati adóügyek intézése) pedig egy hosszú (27 oldalas, más oldalakon már látott) PDF-re mutat, amely a bekezdés címével ellentétben nem önkormányzati adóügyek elektronikus ügyintézéséről szól, hanem egyéb ügyekben (is) ügyindításról, folyamat végigviteléről. Az oldal tulajdonosainak elmondása szerint ezt a 27 oldalas PDF-et központilag meghatározott formában és módon kellett közzétenni (pont ezt és pontosan így) és az nem a helyi ügyintézés része. Ebben a formában azonban sajnos a legkevésbé sem mondható kényelmesen és optimálisan használhatónak. Megoldás lenne egy jól kereshető súgó, általános kereső, vagy még inkább egy könnyen használható, egyértelmű és segítőkész felület, ahol nem kérdés a szóhasználat, sem pedig a végigjárandó folyamat. Ilyet azonban csak részletes kutatás és tesztelések mellett lehet létrehozni.

Az oldal akadálymentes felülete nem felel meg az azzal kapcsolatos ISOszabványoknak (Szántai, 2011). Az oldal tulajdonosai szerint működőképes az oldal, felolvasószoftverrel használható. Azt a tényt, hogy ettől függetlenül még nem akadálymentes a felület, el tudják fogadni. Ugyanakkor hozzátették, hogy anyagi forrás hiányban nem tudják továbbfejleszteni

Pozitívumként érdemes megemlíteni, hogy az oldalon többféle színösszetétel választható, illetve a betűméret is beállítható. Kevésbé nevezhető pozitívnak a „beszédes link”, amelyben a „vakbarát” kifejezéssel élnek, amely sértő lehet a célcsoport tagjai számára: http://www.szombathely.hu/vakbarat/ 


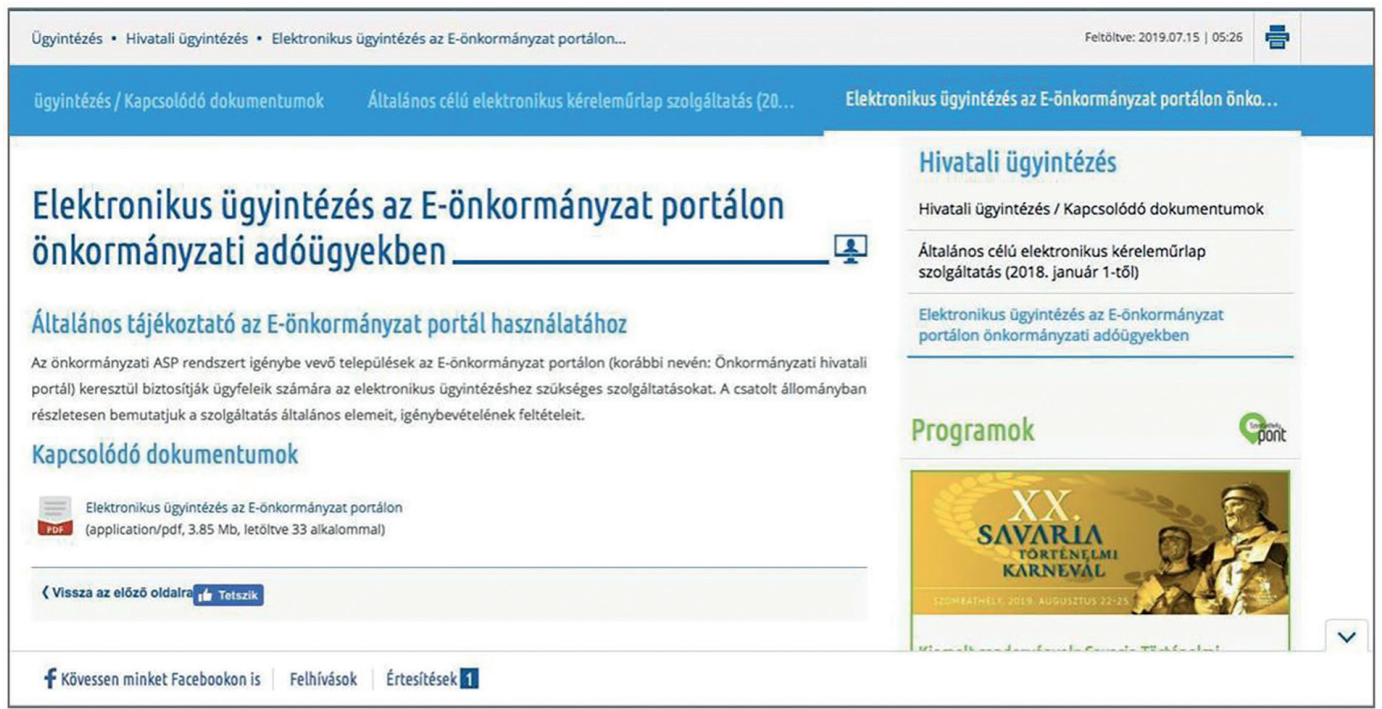

16. ábra: Elektronikus ügyintézési lehetőség és a hozzá letölthető magyarázó, 27 oldalas PDF. (Letöltés: 2019. augusztus 1.)

Ami a vizsgált szempontokat illeti, nem érvényesül az oldalon Nielsen 9-es és 10-es aranyszabálya sem. Az ügyintézésről szóló 27 oldalas letölthető PDF sem feltétlenül könnyíti meg a helyiek életét (hosszú, nem életszerü). Ezzel - a Nielsen heurisztikában szereplő - megállapítással az oldal tulajdonosai nem értettek egyet. Szerintük az oldalnak olyannak kell lennie, hogy súgó használata nélkül is érthető legyen, és maximum ügyintézési, bonyolult felülethez lehet szükséges a súgó vagy az interaktív ügyintézés estén. Ezzel teljesen egyetértünk. Ugyanakkor a hivatkozott Nielsen-i heurisztika arról szól, hogy kérdés-bizonytalanság esetén helyben, azonnal elérhetők legyenek kisebb-nagyobb hintek, segítségek, és a menüszinten strukturált, kereshető súgó-dokumentáció.

Nem könnyíti meg a felhasználók, hogy a felületen nem-szokványos, megszokott logók láthatók (lásd például a 17-es ábra alsó részén látható logó sort). A vizuális felületek tervezése során a vonatkozó szakirodalom (Chiranjeev et. al 2002) szerint érdemes ugyanis olyan logókat (lehetőség szerint pont úgy és pont azokat) használni, amelyeket a felhasználók jól megszoktak és emiatt azonnal meg is értenek. Azt a megoldást pedig, hogy a tervezők tervezik meg és/vagy választják ki a logókat (mivel ők természetesen értik, hiszen ők tervezték, ezzel szemben a felhasználók számára nem feltétlenül egyértelműek) nem javasolja a szakirodalom. A szombathely.hu oldalon (web és mobilapp) szereplő logók nehézkesebben érthető volta már egy egyszerübb felhasználói teszt során is kiderül(hetett volna). A logók értelmezése során ugyanakkor segítséget jelent az, hogy mouse overre megjelenik a menüpontok tartalma, megnevezése (desktopon igen, mobilon ez az opció nem reális).

A logókkal kapcsolatos megállapításunkkal az oldal tulajdonosai nem értettek egyet, szerintük minden logót minden felhasználó tökéletesen ért, és 
ugyanazon logók szerepelnek a Közgyülés oldalon a felső és az alsó sorban. Ez igaz is, de ez mindaddig fel sem tűnt nekünk, amíg nem hívták fel rá külön a figyelmünket. Ennek oka az lehet, hogy formára ugyanazok ugyan a logók, de inverzben szerepelnek. A fehér alapon türkizt látni nem ugyanaz, mint a kék alapon fehéret, de ez csak egy apróbb észrevétel. Ugyanakkor el kell ismernünk: valóban nehézséget jelenthetett általánosan elterjedt logót találni olyan tartalmakhoz, mint közgyülés vagy ügyintézés.

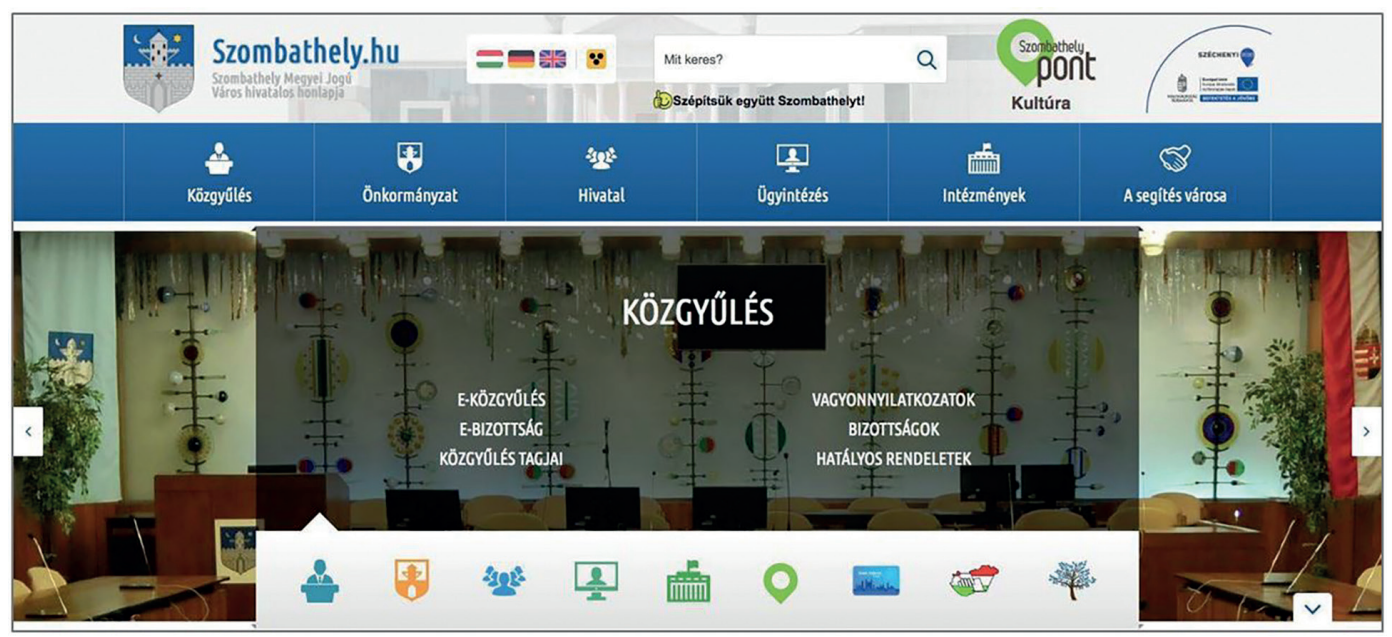

17. ábra: Menüpontok Szombathely weboldalán, a Közgyülés aloldalon: a logók csak mouse over felirat segítségével értelmezhetők. (Letöltés: 2019. augusztus 1.)

Az oldalon a magyar mellett angol és német nyelvü opció is van, de az így elérhető aloldalak csupán a polgármesteri köszöntőt tartalmazzák. Ez azonban helyi döntés volt, miszerint csak olyan részeket fordítottak le, amelyek nem érintik a hatósági tartalmakat.

A kézirat zárásakor (2019 szeptember) az oldalon belül, két aloldalon két különböző polgármester köszöntője is elérhető, a korábbi polgármester, Dr. Puskás Tivadar hosszabb köszöntővel, az új polgármester, Dr. Nemény András pedig még csak képpel szerepelt a felületen.

\section{Tiszaújváros}

\section{Áttekintés}

Tiszaújváros Polgármesteri Hivatalában az átlagos munkatársi létszám 76 fő. A munkavégzéshez szükséges hardverállomány mennyisége és minősége jó, a gépek több mint 50 százaléka két évnél fiatalabb. Tiszaújvárosban az egyik legmagasabb az egy főre eső adóerő-képeség, így az önkormányzat is nagyobb 
költségvetésből gazdálkodik. Ennek következménye, hogy az éves informatikai keret - a hivatal méretéhez és a PC-k számához képest - viszonylag magasnak mondható, így korszerűsítésre, fejlesztésre jócskán adódnak lehetőségek a hivatalban.

A http://www.tiszaujvaros.hu/ második generációs információszolgáltató webhely. A települési szolgáltatások széles skálájáról érhető el információ (például szociális-kulturális ellátórendszer, egészségügy, közrend stb.). Számos átlinkelési lehetőség biztosított a helyi szolgáltatók honlapjára, ahonnan még több információt nyerhetünk.

A közösségi kapcsolódás, a közösségi tartalmak felhasználási lehetősége előtt egyelőre zárt az oldal. Ügyfélszolgálat nincsen, időpontfoglalás okmányirodai ügyintézés esetében lehetséges. Hírlevél, vendégkönyv nem található.

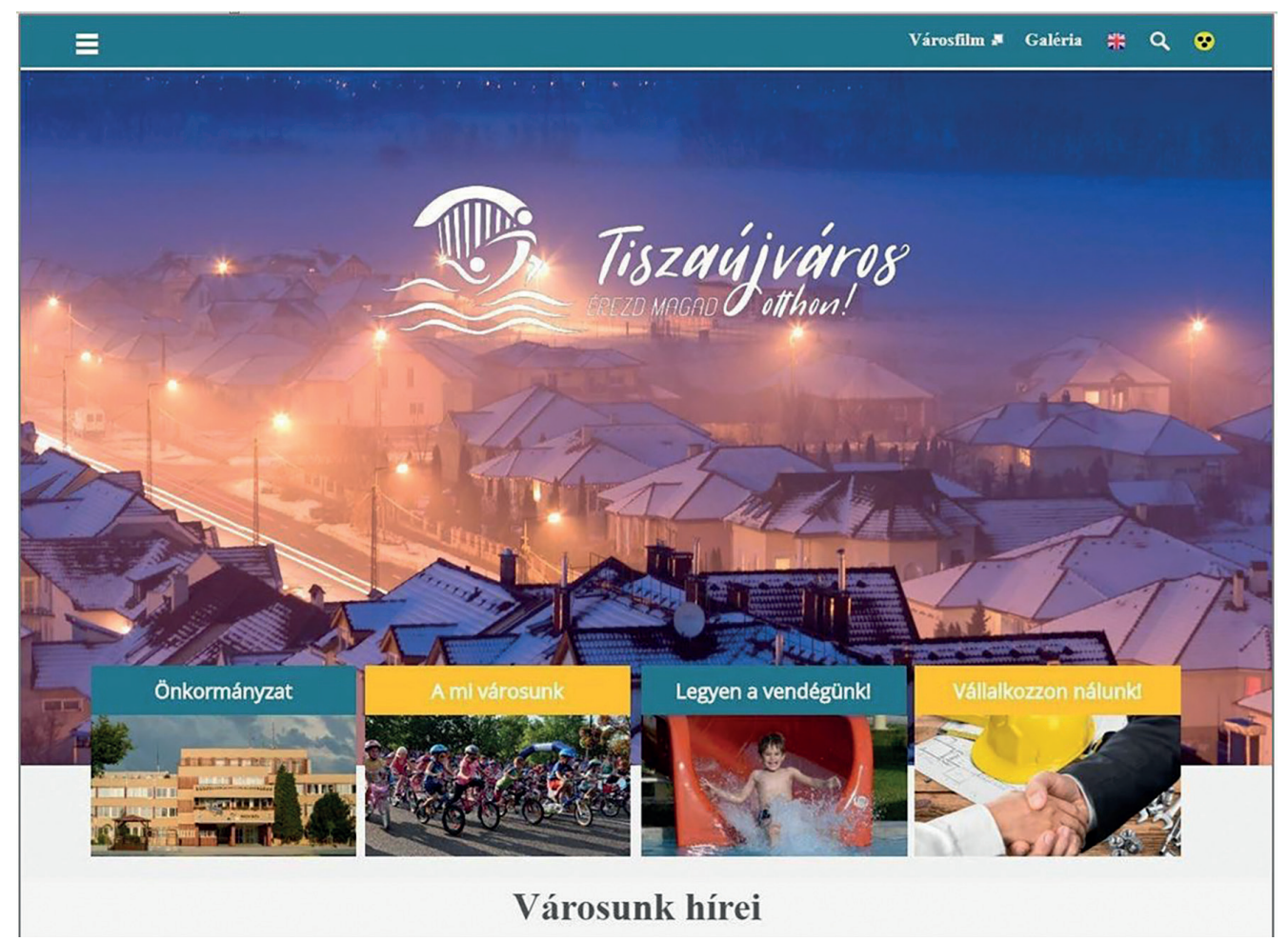

18. ábra: www.tiszaujvaros.hu (Utolsó elérés: 2019. február 02.)

Az oldal tematikusan rendszerezett, menüelemei között kissé nehéz a navigálás. A nyitólap grafikus és szöveges menüpontokat is tartalmaz. A főmenük menüpontjai aloldalakra irányítanak, ahonnan nem lehet visszatérni a főmenübe, újra kell kezdenünk a keresést. Az oldalkép tiszta, ám az oldal a hivatalos jelleget kifejező, egyértelmű címmel nem rendelkezik. Az aloldalak közül kettő közigazgatási információkat hordoz (A mi városunk, Önkormányzat), kettő pedig idegenforgalmi és gazdasági információkat nyújt (Legyen a vendégünk!, Vállalkozzon nálunk!). 
Keresőablak a főoldalon található. A keresés pontosítását, szűkítését felajánlja, így az olykor nagy találati eredmény könnyen szükíthető. Az ügyfélkapcsolat minősége magas szintű, az interaktív kommunikáció eszközeit alkalmazzák, mivel panasz, ötlet bejelentésre külön felületet hoztak létre az oldalon („Üzenjen nekünk!”). Ingyenes zöldszámos telefonos bejelentővonal is müködik.

A kezdőoldal központjában a hírek, programok, aktualitások állnak, melyek frissek. Emellett a kezdőoldalon az Európai Uniós pályázatokról, a helyi közalapítványról, a helyi médiáról és egyéb közérdekű információkról tájékozódhatunk.

Az oldalon akadálymentesítés címén sárga-fekete megoldás érhető csak el, és információt is csak magyar nyelven tartalmaz. A felolvasható megjelenést az oldal nem támogatja, braille interfész nem szerepel, változtatható betűméret funkció van.

Mozgássérülteknek, koordinációs problémákkal küzdőknek: egér kiváltása, hangvezérlő interfész, tetszőleges várakozási idő az interakciók során nem került beépítésre.

Az oldal nagy hátránya annak egyértelmű lassúsága (Google PageSpeedInsights). Ügyintézést végezni a portál ügyfélterminálján lehet, online módon (Elektronikus

Tájékoztató Rendszer - http://ugyfelterminal.tujvaros.hu/). Letölthető nyomtatványok, ügyleírások állnak itt rendelkezésre.

A honlap külön aloldaláról érhető el az Önkormányzati Tájékoztató Rendszer, melyben az önkormányzati munkával kapcsolatos dokumentumok öszszesítetten találhatók meg (a testületi ülések előterjesztései, jegyzőkönyvei, az önkormányzati rendeletek és határozatok).

További szolgáltatásként a honlap újabb aloldaláról érhető el a Dokumentumtár.

Ebben körülbelül 17000 dokumentum szerepel a helyi önkormányzati cégekről, intézményekről. A dokumentumok egy része nyilvános, a lakosság vagy az egyes intézmények részére is elérhető.

Számos ügymenettípus érhető el elektronikus úton a lakosság és a vállalkozások számára, így elektronikus ügyintézés valósulhat meg több területen is.

\section{A tiszaújváros.hu tervezése, fejlesztése, tesztelése, UX szempontok}

Tiszaújváros 2001 óta üzemeltet saját weboldalt. ${ }^{12}$ Az első verzió statikus formában tartalmazott információkat a városról a helyi lakosok és turisták számára. 2017 óta az összes saját tulajdonú weboldalt központilag szerkesztik és üzemeltetik: ez a kézirat elkészültekor 17 különböző weboldalt jelent.

\footnotetext{
${ }^{12}$ A weboldallal kapcsolatos információkat Kiss Csaba informatikai munkatárs, a Tiszaújvárosi Polgármesteri Hivatal részéről bocsátotta rendelkezésünkre.
} 
A vizsgált oldallal - tiszaujvaros.hu - kapcsolatban az önkormányzat részről elmondták, hogy a tervezés folyamatába az érintett terület szakembereit bevonták, a tervezés és fejlesztés folyamán egyszerre folyt a tartalom és a grafika fejlesztése, egymáshoz illesztése. Az oldalt tesztelték is, „az érintett felhasználók egyes csoportjaival”, ez azonban „egy 5-10 fős csoport jelentett, főleg cégen (önkormányzaton) belüli felhasználókkal, akik «civilben» használták az alkalmazásokat. Ők voltak azok, akik egyes funkciókat saját adataikkal leteszteltek és a visszajelzéseik alapján javítottuk az alkalmazásokat.” Az államilag fejlesztett ügyintézési felületeket is tesztelték, „egy helyi adózási nyomtatványt próbáltam végigvinni, (sikertelenül :) )”. A fejlesztésekkel kapcsolatban jellemzően kis létszámú csoportok véleményét kérték ki.

A kész szolgáltatásokat tesztelték is, de ez csupán etikus hekkelésben és terhelési próbákban merült ki. A látogatói számot folyamatosan figyelemmel követik Google Analytics segítségével.

Elektronikus szolgáltatásokat 2017-ig fejlesztettek az oldalon, de ez csak alapszintű funkciókban merült ki. Egy, az önkormányzati, közigazgatási feladatokat ellátó szolgáltatás prototípusát is elkezdték tervezni, „de a 2018. évben kötelezően bevezetett állami ASP rendszer ennek egy részét okafogyottá tette”.

Az önkormányzatok számára kötelező elektronikus ügyintézési felületeket, mivel nem önkormányzati feladat, az önkormányzatok készen kapták. Sem a tervezésbe, sem a fejlesztésbe vagy a tesztelésbe nem vonták be őket.

Tiszaújváros tehát igen széles körben üzemeltet tájékoztató oldalakat, városi mobilapplikációt (CityApp Tiszaújváros) és igen jelentős összegeket költ az informatikai infrastruktúrára. 2018. évtől az állam megjelent mint e-közigazgatási szolgáltató „kötelezően igénybe vehető” szolgáltatásokkal, ami az önkormányzatok ilyen irányú erőfeszítéseit semmissé tette és igen beszűkítette az ilyen irányú fejlesztéseket. Ami megmaradt önkormányzati e-közigazgatási jogkör, az önkormányzat által adható kategória. Tiszaújváros is, mint a többi önkormányzat, arra vár, hogy az állam a meglévő eszközeit milyen mértékben teszi elérhetővé az egyedi igényeikhez. Emiatt most az e-közigazgatás le nem fedett területeivel kapcsolatosan várakozó állásponton vannak. Tiszaújváros iparosodott volta miatt az ott élő szakképzett lakosok magas száma és a városban prosperáló vállalati kultúra miatt mindig magas volt az igény az elektronikus tájékoztatásra, az ilyen típusú elektronikus ügyintézésre. ${ }^{13}$

\section{Tiszaújváros weboldala, Nielsen és Shneiderman heurisztikái alapján}

A weboldal felületei nagyjából egységesek, végigvonul rajta a - nem konzisztensen használt - csempés felület. Ez igaz a mobilos verzióra is.

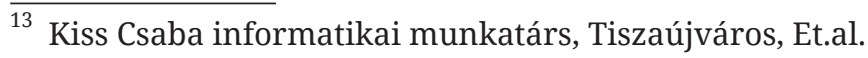


A fejlécben található hamburger menü menüpontjai csak kattintásra jelennek meg és tünnek el. Menüpontjai könnyen követhetők. Ugyanez a bontás menüstruktúra - a mobilos felületen is látható.

Az oldalon látható csempék kattintása-koppintása a mindkét felületen nehézkesebb, mint megszoktuk: a képre húzva az egeret, először megváltozik a kép, megjelenik ismét a link szövege. A teljes felületre azonban így sem lehet kattintani, hanem csak megjelenő a szövegre és a link-ikonra. Ez a megoldás mégpedig a tervezési minta - így ellentmond Nielsen 4. heurisztikájának.
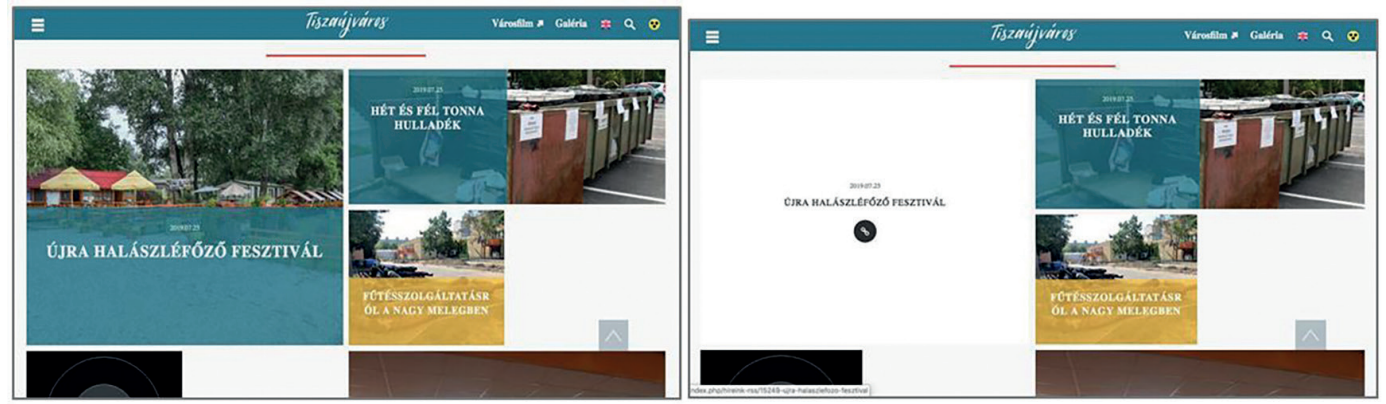

19. ábra: Csempék használata az oldalon. (Utolsó letöltés: 2019. július 30.)

Az összes aloldaltól kettő különbözik, és gyaníthatóan az azokon található információk indokolhatják ezt, az Elektronikus ügyintézés vagy E-közigazgatási felület43 és Tiszaújváros Polgármesteri Hivatal aloldala.

A „Járási hivatal” linkre kattintva pedig egy merőben más stílusú és felépítésű, külső, központi felületre érkezik a felhasználó.

Ugyanitt, a „Tiszaújváros polgármesteri hivatal” linkre kattintva szintén más felépítésű oldalt találunk (lásd: 20-as ábra).

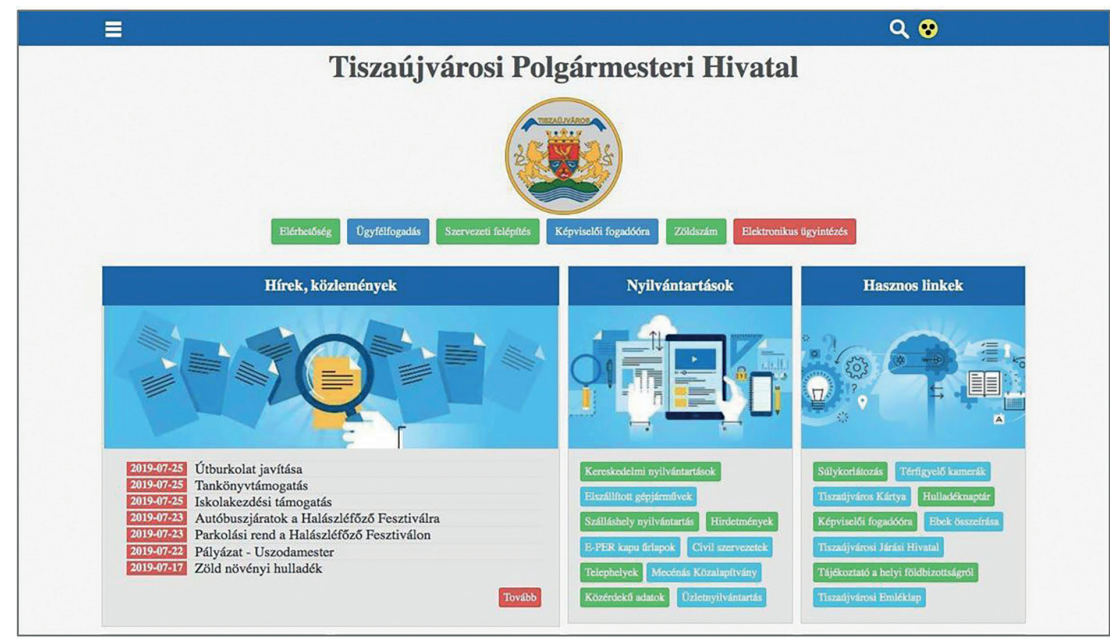

20. ábra: Tiszaújvárosi Polgármesteri Hivatal, aloldal. (Utolsó letöltés: 2019. július 30.)

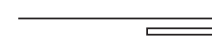




\section{A négy oldal összefoglaló értékelése}

Bár a legnagyobb városok oldalán egyre több elektronikusan intézhető üggyel találkozunk, az oldalak vezérlőelve nem a szolgáltatások virtuális térbe helyezése, illetve a közösségi bölcsesség felhasználása a települési problémákra. Döntően megrekedtek a második generációs webhelyeknél, azaz az információszolgáltatás, ügyindítás, ügymenet-mozzanat vállalása vonulatnál, kiegészítve az állami rendszerek oldalba integrálásával (SZEÜSZ szolgáltatások). Valamennyi oldal feltételez előzetes felhasználói közigazgatási tudást, melynek hiánya esetén a keresők és a felhasználói felületek (megfelelő részletességủ és felépítésủ súgóval, mouse over segítséggel stb.) nem veszik le a terhet a felhasználó válláról. Nehézséget okoz a fejlesztés során, hogy a közigazgatási űrlapok a jogszabályok alapján készülnek, tehát az önkormányzatoknak nincs joga azokban módosítást eszközölni.

Nehézséget okoz az is, hogy a felhasználók segítése jórészt kimerül a többször is említett, sokoldalas, kötelezően közzéteendő központi PDF letöltési lehetőségével.

A legnagyobb magyar városok - kivétel nélkül - rendelkeznek e-közigazgatási aloldallal, azonban az egyes ügyek intézését sem biztosítják egyformán. Az általunk vizsgált portálok a hazai gyakorlat legjobbjai közé tartoznak, azonban bőven van rajtuk is fejlesztési potenciál. A kisebb településeknél - így az ország egészét tekintve - ennél lényegesen rosszabb a helyzet. Majdnem mindegyik valamilyen autentikációt (többnyire ügyfélkapus belépést) igényel ${ }^{14} \mathrm{az}$ online eljárások feltárásához. Az online eljárások pedig vagy kimerülnek egy (ÁNYK-s) nyomtatvány kitöltésében ${ }^{15}$ vagy az e-papír szolgáltatásban. Ezeket a megállapításokat más tanulmányok is alátámasztják (Hoffman et. al. 2018.)

A nagyvárosi honlapok külsejükben, struktúrájukban egymástól teljesen eltérnek, így a városi közigazgatás logikája webhelyen keresztül nehezen lenne tanulható ${ }^{16}$ (például egy városváltó állampolgárnak).

A vizsgált felületek láthatóan, többnyire igyekeznek követni az aktuális design trendeket, vizuális értelemben szebbek, áttekinthetőbbek, mint ko-

\footnotetext{
${ }^{14}$ A Szombathely.hu oldal részéről ezzel kapcsolatosan Keringer Zsolt megjegyezte, hogy „a jogszabály 2018. január 1-től rendelkezik az elektronikus kapcsolattartás módjáról” és a városoknak ezt kell alapul vennie, még ha az az ügyfeleknek kényelmetlenséget is jelent sok esetben. Elmondása szerint a „másik alapprobléma, hogy a GDPR is olyan feltételeket szab, ami nem segíti éppen elő a könnyebb elektronikus kapcsolattartást”.

${ }^{15}$ Keringer Zsolt hozzátette: „a nagyvárosok tekintetében ez idáig az ANYK volt a prioritás központilag. Mi Szombathely vonatkozásában már elkezdtük az IFORM ürlapok használatát, mert ez év második felétől engedélyezték. A jogszabályban is meg van határozva miket és milyen technológia alapján használhatunk. Tehát ez (a helyzet - szerk.) nem önkormányzati hiba vagy mulasztás, hanem jogszabályi megfelelés betartása!”

16 „(...) régebben volt egy törekvés az egységes szerkezet megalkotására hivatali ügyintézést illetően, amit el is készítettünk MJVSZ vonalon, de sajnos nem lett ebből semmi. Akkor hat város közreműködésével csináltuk meg” - tette hozzá szintén Keringer Zsolt.
} 
rábbi verzióik. Ugyanakkor a tervezés-fejlesztés-tesztelés menete legtöbbször némiképp elavult és pénzhiánnyal küzd, így - Miskolc kivételes megoldásától eltekintve - rendre tapasztalható a visszatérő káros fejlesztési és kutatási gyakorlat, például amikor a készülő felületet tesztelik ugyan, de azt az önkormányzati alkalmazottakkal teszik („elképzeltem, hogy helyi lakos vagyok” vagy „arra kértük a tesztelő "alkalmazottakat», hogy képzeljék el, hogy helyi lakosok” (sic!)). Ugyaniebbe a kategóriába tartozik, amikor a tervezők az egyeztetés, tesztelés helyett a ,józan mezőgazdasági észjárást” követték. Ezzel, a közigazgatásban is általánosan jellemző, egyébként káros és nem túl észszerü gyakorlattal kapcsolatosan a rendelkezésre álló szakirodalom tanúsága szerint a fejlesztő bármennyire is szeretne, sohasem tud a felhasználó fejével gondolkodni. Többek között azért nem, mert eltérő szakmai hátterük van, eltérő tapasztalataik, eltérő mentális modelljük.

UX-szakembereként és kutatóként végzett munkánk pontosan ezen a feltevésen alapul: különbözünk a felhasználóktól. A nekünk megfelelő felületek nem feltétlenül azok a felhasználóink számára is: nem tudjuk megítélni a felhasználói felület minőségét csupán az alapján, hogy mi kedveljük vagy értjük-e a terveket. Úgy tesztelni egy felületet, hogy feltételezzük, mi vagyunk a felhasználóink, téves út. Ezt a pszichológia hamis konszenzushatásnak (vagy egocentrikus attríbúciós elfogultságnak ${ }^{17}$ nevezi (Ross et. al.1977, Raluca, 2017). Mivel at adott felület felhasználói nem mi vagyunk, mindig szükséges tesztelni a készülő felületünket is a felhasználók megfelelően kiválasztott célcsoportjával.

Ha ez a fajta tesztelés, ügyfélközpontú hozzáállás kimarad a fejlesztésből, előfordulhat, hogy a kész felület nehezebben érthető, helyenként - felhasználói és kutatói szemmel nézve is - némileg zavaros. Pedig a most bemutatott kutatásban feltárt problémák nagy része néhány egyszerübb felhasználói teszteléssel is kiszűrhető lett volna. Különösen igaz ez Szeged város weboldalára, ahol a teljes fejlesztés során egyszer sem beszélgettek a felhasználókkal és a „józan paraszti észjárásra” alapoztak. Az pedig, hogy a tesztelés mennyiben teheti jobbá a felületeket, jól mutatja Miskolc és Szombathely weboldalának példája, amelyeken alapvetően viszonylag jól (az összes közül a legjobban Miskolcon) érvényesülnek a hivatkozott aranyszabályok és heurisztikák. A szabályok univerzális jellegét és létjogosultságát jól mutatja, hogy úgy vált ennyire jól használhatóvá a felület, hogy az azt fejlesztők, elmondásuk szerint nem is tudtak e szabályok létezéséről, nem használták azokat tudatosan (se).

Tesztelni tehát mindenképpen érdemes, mégpedig a fejlesztés teljes folyamatban, a megfelelő módszertannal, megfelelő résztvevőkkel. Ez nem csak azt

\footnotetext{
17 „(...) az önkiszolgáló torzítások egyik fajtája: az emberek vagy csoportok szívesen feltételezik, hogy attitűdjeik, véleményeik, értékeik vagy viselkedésmódjuk valójában egybeesik az emberek többségének attitűdjeivel, értékeivel, nézeteivel és viselkedésével. A hamis konszenzus elmélete szerint hajlamosak vagyunk azt gondolni magunkról, hogy „normális emberek” vagyunk, ami magában foglalja azt a viselkedést is, hogy fontos vonatkozásokban hasonlóak vagyunk a körülöttünk levő „legtöbb emberhez” (Radula, 2017).
} 
jelenti, hogy a fejlesztés aktuális szakaszához illeszkedő módszertant érdemes választani, hanem azt is, hogy az adott módszertan alkalmazása során jól választjuk ki kutatási alanyokat is: vagyis nem az önkormányzati alkalmazottakkal, sem a családtagjainkkal vagy programozókkal végzünk felhasználói tesztelést, hanem valódi állampolgárok, helyi lakosok részvételével. ${ }^{18}$

Többször felmerült az a gondolat is, miszerint leginkább az állampolgároknak kellene jobban ismerniük a jogszabály által meghatározott kötelezettségeiket és megtanulni jól használni a felületeket, növelni a digitális érettségüket, képzettségüket (digitális írástudásukat). Itt röviden utalnánk vissza a Bevezetésben bemutatott és citált 2018-as NMHH felmérés eredményeire, miszerint a 16 évesnél idősebb internetezők 77-72 százaléka már online tájékozódik és vásárol is, 52 százalékuk online bankol, és csupán 37 százalékuk használja az online közigazgatási ügyintézési lehetőségeket. Úgy véljük, az elmaradás oka nem a felhasználók alacsony digitális írástudása, hanem az, hogy a közigazgatási felületek jellemzően kevésbé jól használhatóak, nehezen érthető a nyelvezetük. Problémát jelent a felhasználók számára az is, ha minden esetben a jogszabályban szerepelő kifejezéseket használják az online felületen (lásd például menüpontok is), és felépítésük a hivatali gondolkodást követi, fogalmazásuk bonyolult stb.. Ugyanígy problémás az is, hogy a weboldalak akadálymentes verziója legtöbbször nem felel meg az alapvető akadálymentességi szabályoknak.

Igazi kihívásnak tűnik mindez a közigazgatás számára, bár jó megoldások már most is láthatóak, lásd a bemutatott városi oldalak egy részét vagy a hivatkozott két nagyobb állami példát. A felhasználói felületek UX-szempontú létrehozásának fontossága mellett érdemes utalni a plain language szükségszerű térhódítására is: a közigazgatási szféra sem teheti meg, hogy idővel ne legyen tekintettel arra, hogy az állampolgárok igénylik az egyszerúen megfogalmazott gondolatokat, könnyen érthető szövegeket (lásd: vilagosbeszed.hu).

\footnotetext{
${ }^{18}$ Az időnként előforduló szemléletet jól mutatja egy név nélküli, kutatás során velünk megosztott fejlesztői idézet: „A tesztelések esetén szerintem itt másról beszélünk. A lakosságnak a portált alapvetően nem lehet bemutatni, mert ez elvárás!!!! A szakmai és jogi elvárásokat a lakosság nem tudja, így igazi tesztelésre bevonni ennek ismeretében lehet nehézkes lenne. Mi bevonunk saját családunkból embereket, hogy nézzék meg, de szerintem az elektronikus ügyintézés esetén a jogszabályi megfelelést ők nem tudják! A BANK sem szokott bevonni senkit a saját üzletmeneteinek tesztelésébe!” (Szerző megj.: a banki weboldalakat mára csak kizárólag komoly, részletes felhasználói tesztelések után publikálják).
} 


\section{Irodalom}

2011. évi CXII. ma is hatályos törvény

Dr. Aranyosi Gergő: Egy dizájnos honlap is lehet akadálymentes!

https://ithon.info/blog/2019/04/18/egydizajnos-honlap-is-lehet-akadalymentes

Arios-NRC. LAKOSSÁGI INTERNETHASZNÁLAT ONLINE PIACKUTATÁS. Kutatási jelentés az NMHH részére. Ariosz - NRC, Budapest, 2018.

http://nmhh.hu/dokumentum/202180/lakossagi internethasznalat 2018.pdf

Barnes, S. - Richard Vidgen: Interactive e-government services: modelling user perceptions with eQual. InderScience Online, 2004.

https://www.inderscienceonline.com/doi/pdf/10.1504/EG.2004.005179 2004. DOI 10.1504/ EG.2004.005179

Betz, Joachim - Hans-Dieter Kübler: Internet Governance. Springer Fachmedien Wiesbaden, 2013. https//link.springer.com/book/10.1007/978-3-531-19241-3

Budai Balázs Benjámin (szerk.). Kutatási jelentés - Kutatás III. Az önkormányzatok információfeldolgozási képességeit ( $p l$. fejlesztési, tervezési, együttmüködési, módszertani stb.), szükségleteit és a továbblépés lehetőségeit meghatározó kutatás. Belügyminisztérium, Budapest, 2018.

Budiu, Raluca (2017): You Are Not the User: The False-Consensus Effect. https://www.nngroup. com/articles/false-consensus/ (Utolsó elérés: 2020.12.20.)

Bundesinstitut für Bau-, Stadt- und Raumforschung: Smart City Charta-Digitale Transformation in den Kommunen nachhaltig gestalten. Bundesamt für Bauwesen und Raumordnung (BBR), 2017.

Fitzsimmons, C. 2013. Email is dead, long live email: Six tips on how to use it better. BRW. Melbourne, Vic.: Fairfax munkáját idéz Anne Howard: The What, How and Why of Social Media - A Guide for Local Government, A Report for Sydney Coastal Councils Group. Howard Partners Pty Ltd May 2013

Herendy Csilla: Káros fejlesztési gyakorlatok. Online kommunikációs kihívások a közigazgatásban. Magyar Urbanisztikai Társaság: In: Magyar Urbanisztikai Társaság: Városi válaszok a globális gazdasági kihívásokra és a technológiai trendekre, különös tekintettel az intelligens városok modelljére. 2015, Budapest.

http://smartcity.debrecen.hu/assets/media/file/hu/140/cities in action global challenges and smart city 2015. pdf

Herendy Csilla (2019): Miért fontos a user experience, a mentális modellek kutatása, és mi közük van a közigazgatáshoz? NKE, Közszervezési és Közigazgatástani Intézet, Intézeti kötet 2019.

https://akk.uni-nke.hu/document/akk-uni-nke-hu/k\%C3\%B6zigmuhely44.pdf

Herendy Csilla: Tekintetkövetéses vizsgálat és online fókuszcsoportos pilot-kutatás a magyarország.hu oldalon. JEL-KÉP: KOMMUNIKÁCIÓ KÖZVÉLEMÉNY MÉDIA, 2008, 5780. old. http://real-j.mtak.hu/5609/2/JelKep 2008 3.pdf

Herendy Csilla: Digitális megoldások a turizmusban és a közigazgatásban: fejlődés, fejlesztés és a hiteles beszállító-választás szempontjai. In: Szilvássy, István (szerk.) Innováció és Identitás települési, vidéki, regionális dimenzióban. Tudományos-közéleti konferencia. konferencia-kötete. Budapest: Magyar Település- és Területfejlesztők Szövetsége, 2019. 
Hoffmann István, Cseh Kristóf Balázs, Jugovics Andrea; Nevenka, Žarkić-Joksimović (szerk.); Sanja, Marinković (szerk.) E-administration and the Municipal Authorities: The case of the Hungarian Large Municipalities. Belgrade: University of Belgrade, Faculty of Organizational Sciences, 2018.

Internet World Stats, 2019. https://www.internetworldstats.com/stats.htm

ITU Committed to connecting the world https://www.itu.int/en/ITU-D/Statistics/Pages/stat/ default.aspx

Jong, Menno D. T. De - uYuguang. „Functional Complexity and Web Site Design: Evaluating the Online Presence of UNESCO World Heritage Sites". Journal of Business and Technical Communication,Vol.32,1998,Issue3.,pp.347-372.https://doi.org/10.1177/1050651918762029

Kohli, Chiranjeev - Rajneesh Suri - Mrugank Thakor. „Creating effective logos.

Insights from theory and practice”. Business Horizons, May-June, 2002, pp. 58-64. DOI: 10.1016/S0007-6813(02)00203-3

Nielsen, Jakob. 10 Usability Heuristics for User Interface Design, 1994. https://www.nngroup. com/articles/ten-usability-heuristics/

Nielsen, Jakob. Why You Only Need to Test with 5 Users. NN/g Nielsen Norman Group, 2000 https://www.nngroup.com/articles/why-you-only-need-to-test-with-5-users/

Önkormányzati fejlesztések figyelemmel kísérése II. (ÖFFK II.) című, KÖFOP-2.3.4VEKOP-15-2016-00002 azonosítószámú kiemelt projekt.

Schellong, Alexander - Philipp Girrger: Government 2.0 in der Betaphase January 2011 Edition: CSC Public Sector Study SeriesPublisher: CSC https://www.researchgate.net/publication/231168677_Government_20_in_der_Betaphase Shneiderman, Ben. „The Eight Golden Rules of Interface Design” University of Maryland, É.n. http://www.cs.umd.edu/ ben/goldenrules.html

Szántai Károly. „Nem az akadálymentes verzió a megoldás” Akadalymentesweb, 2013. https://www.akadalymentesweb.hu/2011/08/nem-az-akadalymentes-verzio-a-megoldas/

Szántai Károly. „Honnan ered az akadálymentes verzió sárga-fekete pöttyös ikonja?” Akadalymentesweb, 2015. https://www.akadalymentesweb.hu/2015/11/honnan-ered-azakadalymentes-verzio-sarga- fekete-pottyos-ikonja/

Wirtz, Bernd W., Oliver Schilke és Sebastian Ullrich. "Strategic development of business models: implications of the Web 2.0 for creating value on the internet." Long Range Planing, Elsevier, Long Range Planning, Vol. 43. 2010. Issues 2-3, pp. 272-290.

https://doi.org/10.1016/j.lrp.2010.01.005 